\title{
TIPOS VEGETAIS APLICADOS AO PAISAGISMO
}

\author{
EURICO JOÄO SALVIATI
}

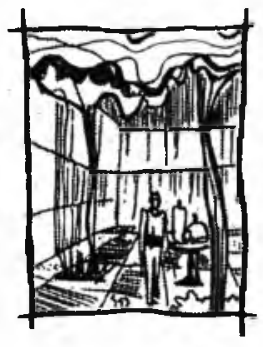

A correta utilização da vegetação em paisagismo requer um profundo conhecimento das espécies vegetais, através de suas características que de um modo geral podem ser agrupadas em dois conjuntos. $O$ primeiro tem a ver com o aspecto visual da planta, forma, tamanho, estrutura, densidade e disposição da folhagem, textura e cores do conjunto e de suas partes vegetais. São aspectos que dizem mais respeito à arquitetura da planta tomada como objeto, ou ainda relacionados à forma como o vegetal ocupa e se desenvolve no espaço.

O segundo conjunto de aspectos refere-se à planta como ser vivo, intimamente relacionada ao seu ambiente, e dele dependendo para se manter, desenvolver, florescer, frutificar. Suas exigências quanto ao tipo de solo, umidade, iluminação, seu tipo de crescimento, ciclos anuais de florescimento e frutificação, suscetibilidade ou resistência a doenças e pragas, são aspectos cujo conhecimento se torna indispensável para sua correta aplicação, embora estes dados nem sempre sejam conhecidos ou estejam disponíveis como seria desejável.

Os tipos vegetais utilizados na linguagem corrente, árvores, arbustos, trepadeiras, ervas, têm muito a ver com o primeiro conjunto de características, relativas à arquitetura da planta. Já os aspectos que se referem ao vegetal como um componente vivo da natureza não estão de modo muito particular relacionadas aos tipos acima mencionados. Embora alguns tipos vegetais, como por exemplo as trepadeiras, possam ser encontrados de preferência em matas ou florestas, que são formações características de climas úmidos, outros, como por exemplo as herbáceas, e entre estas particularmente as gramíneas, são plantas ubíquas, ou seja, que podem ser encontradas nos mais diversos ambientes e climas, com espécies peculiarmente adaptadas a viver nas condições mais adversas.

É bastante comum, quando se elaboram projetos de paisagismo, ao menos inicialmente, lidar com tipos vegetais ao invés de espécies propriamente ditas. Este modo abstrato de trabalhar com a vegetação facilita muito sua utilização como fator de estruturação plástica e ordenamento da paisagem. A especificação propriamente dita pode ser deixada para uma fase posterior do projeto, quando então se torna imprescindível levar em consideração os aspectos naturais de 
cada trecho da área a ser tratada, particularmente os tipos de solo e as variações de umidade e iluminação, fatores que irão influir decisivamente na escolha definitiva das espécies.

Por esta razão é conveniente adotar uma classificação com a qual se possa trabalhar nesta fase inicial de predefinição do estudo de vegetação dentro do projeto. A classificação mais comum de tipos vegetais utilizada na prática refere-se a uma definição que leva em conta exclusivamente o tipo de caule vegetal. Assim, as árvores são plantas providas de um tipo de caule resistente e lenhoso, que se ramifica a uma certa altura do nível do solo, enquanto que os arbustos possuem caule lenhoso, geralmente ramificado desde sua base. Os subarbustos possuem caule apenas parcialmente lenhosos, pois seu prolongamento é herbáceo, enquanto as trepadeiras caracterizam-se por seu caule sempre pronto a se desenvolver e se apoiar sobre outras estruturas mais resistentes. Plantas cujo caule é completamente desprovido de lenho são consideradas herbáceas, independentemente de sua forma e tamanho: diversas musáceas como as helicônias ou as bananeiras, por exemplo, são consideradas herbáceas, da mesma forma que qualquer pequena erva rasteira.

Esta classificação, para ser utilizada em paisagismo, vai necessitar de uma redefinição, na qual torna-se necessário levar em conta outras características além do caule vegetal, tais com forma, porte, estrutura, além de outros detalhes relativos às diferentes partes vegetais. Com base nestes aspectos, que de modo especial se referem à presença física do elemento vegetal na paisagem, será possível definir um conjunto de tipos fundamentais que sejam relativamente fáceis de manusear para fins de projeto.

No quadro é apresentada uma classificação que parte dos tipos elementares correntemente utilizados na prática e estabelece um conjunto de tipos fundamentais, compostos essencialmente com base na forma geral ou feição do vegetal, tipos estes que serão detalhados mais à frente. Contudo, é preciso se ter em conta que qualquer classificação aplicada a um universo tão rico e diversificado quanto o mundo vegetal, estará sempre sujeita a imprecisões, ambigüidades e superposições. Mesmo a simples diferenciação entre árvore e arbusto, que nos pode parecer à primeira vista suficientemente precisa, não tem uma correspondência exata na natureza, onde esta distinção nem sempre é tão clara, pois existem formas intermediárias que poderiam se enquadrar tanto em um tipo quanto em outro ou que dificilmente se ajustariam a algum deles. Por força de uma simplificação inevitável, não raramente são incluídas no mesmo grupo, plantas que têm algumas características importantes em comum, mas que 


\section{ainda assim apresentam entre si diferenças tais que não podem ser inteiramente desprezadas.}

\section{QUADRO:}

1. ÁRVORES: Plantas arbóreas, com estrutura ramificada em diferentes formas, caule único, ramos providos de folhas laminares, com formas e tamanhos variados.

PLANTAS ARBÓREAS:

Plantas com altura

normalmente acima de 5 ou 6 metros, caule autoportante, único na base, reparindo-se acima do nível do solo.

TREPADEIRAS: Plantas de caule não autoportante, que crescem apoiadas em outras estruturas.

PLANTAS ARBUSTIVAS: Plantas até a altura de 5 ou 6 metros, caule em geral subdividido junto ao nível do solo, resistente ao menos parcialmente.
2. PALMEIRAS: $\quad$ Plantas de caule único, provido de folhas alongadas, caracteristicamente pinadas, inseridas em rosetas na extremidade superior do caule.

\section{CONIFERAS: Plantas arbóreas, em geral de grande porte, estrutura} monopodial (caule vertical com ramificaçōes laterais), copa freqüentemente cônica, folha em forma de acículas, lâminas estreitas ou escamas.

\section{TREPADEIRAS}

\section{ARBUSTOS}

6. HERBÁCEAS: Plantas erguidas, geralmente até 1 metro de altura, excepcionalmente podendo atingir a altura de um arbusto, com o caule completamente herbáceo.

\section{PLANTAS HERBÁCEAS:}

Plantas de caule não resistente, herbáceo, com altura raramente acima de 1 metro.
7. FORRAÇŌES: $\quad$ Plantas herbáceas, rasteiras, geralmente em comunidades densamente enraizada, com altura até $30 \mathrm{~cm}$, aproximadamente, que nāo admitem pisoteio. 


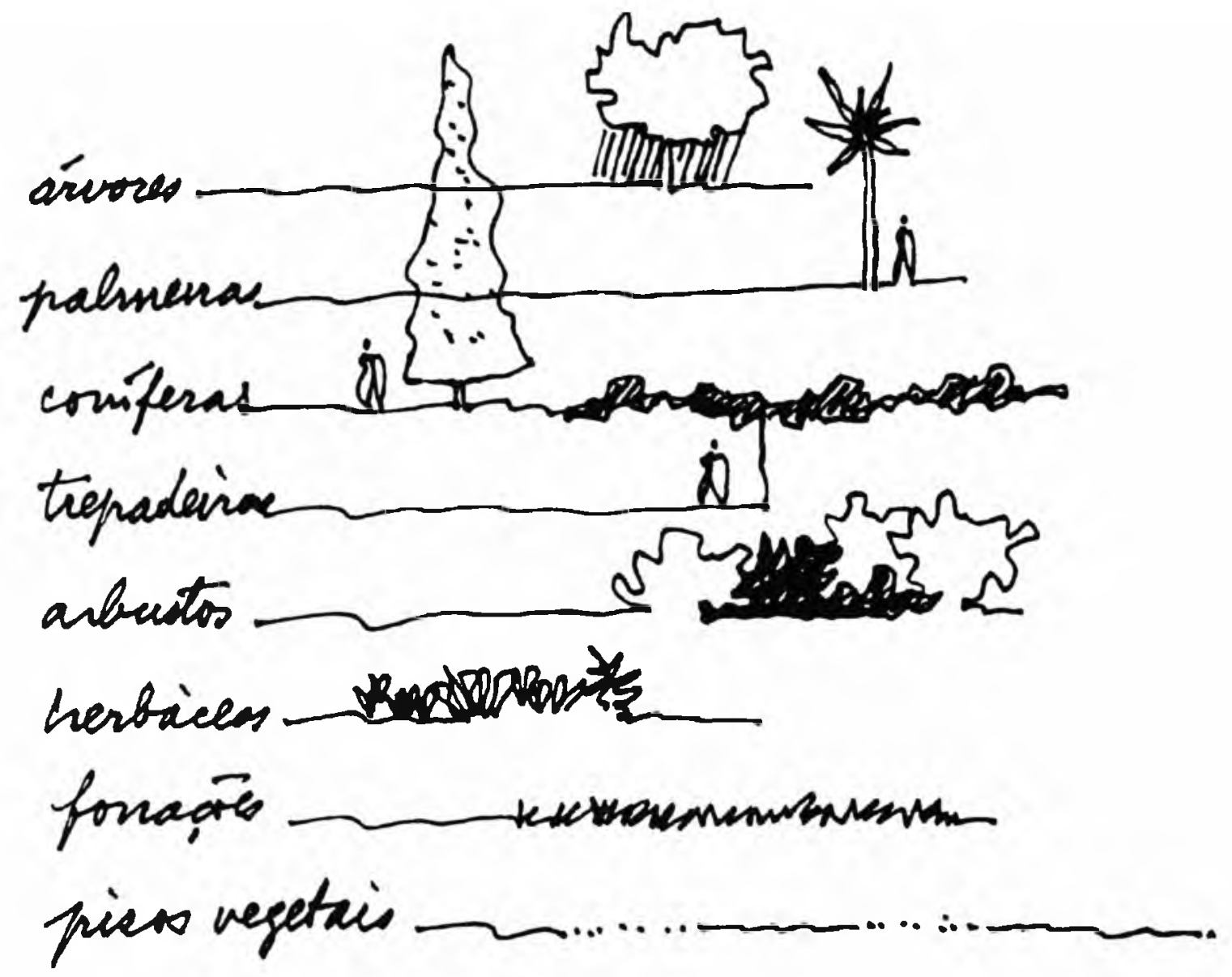

\section{ÁRVORES}

As plantas arbóreas representam o clímax da realização da natureza dentro do mundo vegetal. Atingindo em algumas espécies um porte que pode ultrapassar os $100 \mathrm{~m}$ de altura, impressionam pela perfeição e clareza de sua estrutura e pela mágica profusão de folhas, que se distribuem sempre em busca da luz solar, em permanente mobilidade causada pela agitação do ar, fazendo a copa integrar um constante jogo de luz e sombras, tonalidades e contrastes, que multiplicam seu aspecto ao longo do dia ou através dos meses do ano.

Além de úteis como abrigo, fatores de ordenamento e definição do espaço exterior, podem se constituir elementos simbólicos de extraordinário valor e objetos privilegiados de referência ou de marcação do espaço. Preferimos 
distinguir as árvores das coníferas e palmeiras por considerar que elas desempenham funções diferenciadas na paisagem, pois a árvore pode ser pensada como um verdadeiro teto vegetal, provido de um suporte único, permitindo franca transparência para um observador localizado próximo a sua copa.

Porte, forma e sombreamento: Entre os aspectos que poderão servir para qualificar a árvore como tipo vegetal o primeiro é o seu porte. Quanto a este aspecto é comum se considerar uma gradação de três valores: árvore de grande, médio ou pequeno porte. Uma árvore poderá ser considerada de grande porte seja pela sua altura, como por exemplo o mogno (Swietenia macrophylla), ou o guapuruvu (Schyzolobium parahiba), seja pelo seu diâmetro de copa como acontece com o flamboiam (Delonix regia), ou ainda por ambos como é o caso do pau-de-balsa (Ochroma pyramidale). Os parâmetros que constam da tabela abaixo provêm antes da experiência de projetos de paisagismo que de critérios científicos ou botânicos:

PORTE pequeno médio grande

altura até $8 \mathrm{~m} \quad 8$ a $15 \mathrm{~m} \quad+$ de $15 \mathrm{~m}$

diâmetro até $6 \mathrm{~m} \quad 6 \mathrm{a} 12 \mathrm{~m} \quad+$ de $12 \mathrm{~m}$

É comum ainda se utilizar o termo arvoreta para se designar um tipo de planta que pelo seu porte, até no máximo 5 ou 6 metros de altura, se assemelha a um arbusto, mas que diferentemente destes não possuem o caule subdividido na base. As arvoretas como, por exemplo, o jasmim-manga (Plumeria rubra), a grevilha-anā (Grevillea banksii), a extremosa (Lagerstroemia) indica, algumas espécies de dracenas e chefleras, não podem na verdade ser utilizadas como árvores, porém seu pequeno porte as torna ideais para espaços limitados, que não comportariam plantas de porte mais avantajado, como as árvores propriamente ditas.

Ao analisar a questão da forma das árvores é necessário observar inicialmente que podem existir grandes variações entre indivíduos da mesma espécie, função da variabilidade genética inerente às espécies de modo geral. Além disso, as condições ambientais e em especial as condições de iluminação, modificam substancialmente sua forma e mesmo seu porte, podendo se observar que as árvores nativas encontradas dentro das matas ou aquelas que são cultivadas em locais sombrios, tendem a se alongar em busca da luz, formando uma copa estreita e adquirindo um talhe esguio. Costuma-se, portanto, considerar que a 
forma específica da árvore é aquela adotada quando a mesma se desenvolve isoladamente em condições de plena insolação.

A forma de uma árvore quando plenamente desenvolvida, poderá ser atribuída ao resultado da combinação de duas variáveis: o tipo de fuste e a forma de sua copa, a qual se relaciona intimamente com a estrutura e a conformação de seus ramos. O fuste é geralmente definido como sendo a porção do caule que permanece não subdividido. Para efeito do que interessa ao paisagismo pode ser definido como sendo a porção de caule que se apresenta visualmente liberado, desobstruído da folhagem da copa, não interessando muito onde se inicia sua divisão. Pode se considerar como baixo o fuste com até 2,5 metros, médio o que tem sua altura entre 2,5 e 4 metros, e alto o que atinge mais de 4 metros.

A estrutura de uma árvore é função do modo como as partes responsáveis pelo crescimento da planta (meristemas) se desenvolvem. Em virtude do tipo de crescimento adotado, a árvore poderá ter uma forma acentuadamente vertical, marcado por um único tronco, que ao invés de se dividir apenas lança ramos lateralmente (estrutura monoaxial), ou dispor de uma forma melhor distribuída no espaço, resultante de outros tipos de estrutura, onde o caule se subdivide uma ou mais vezes (estruturas poliaxiais). Como este tema é extremamente complexo, em virtude da grande variedade de formas de crescimento existentes, só nos será possível citar alguns exemplos mais comuns, como os abaixo esquematizados: estrutura monoaxial (1) e estrutura poliaxial (2).
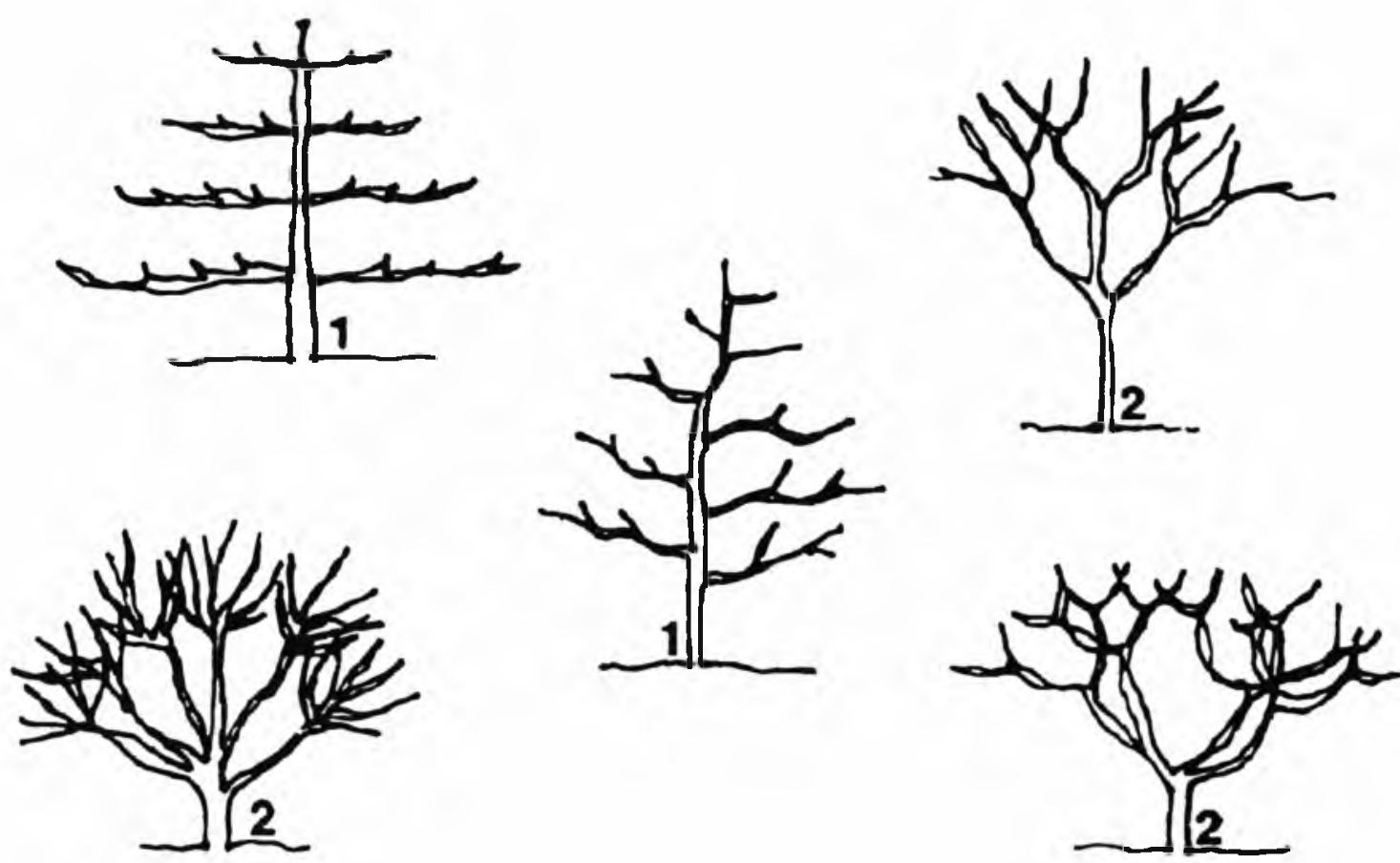

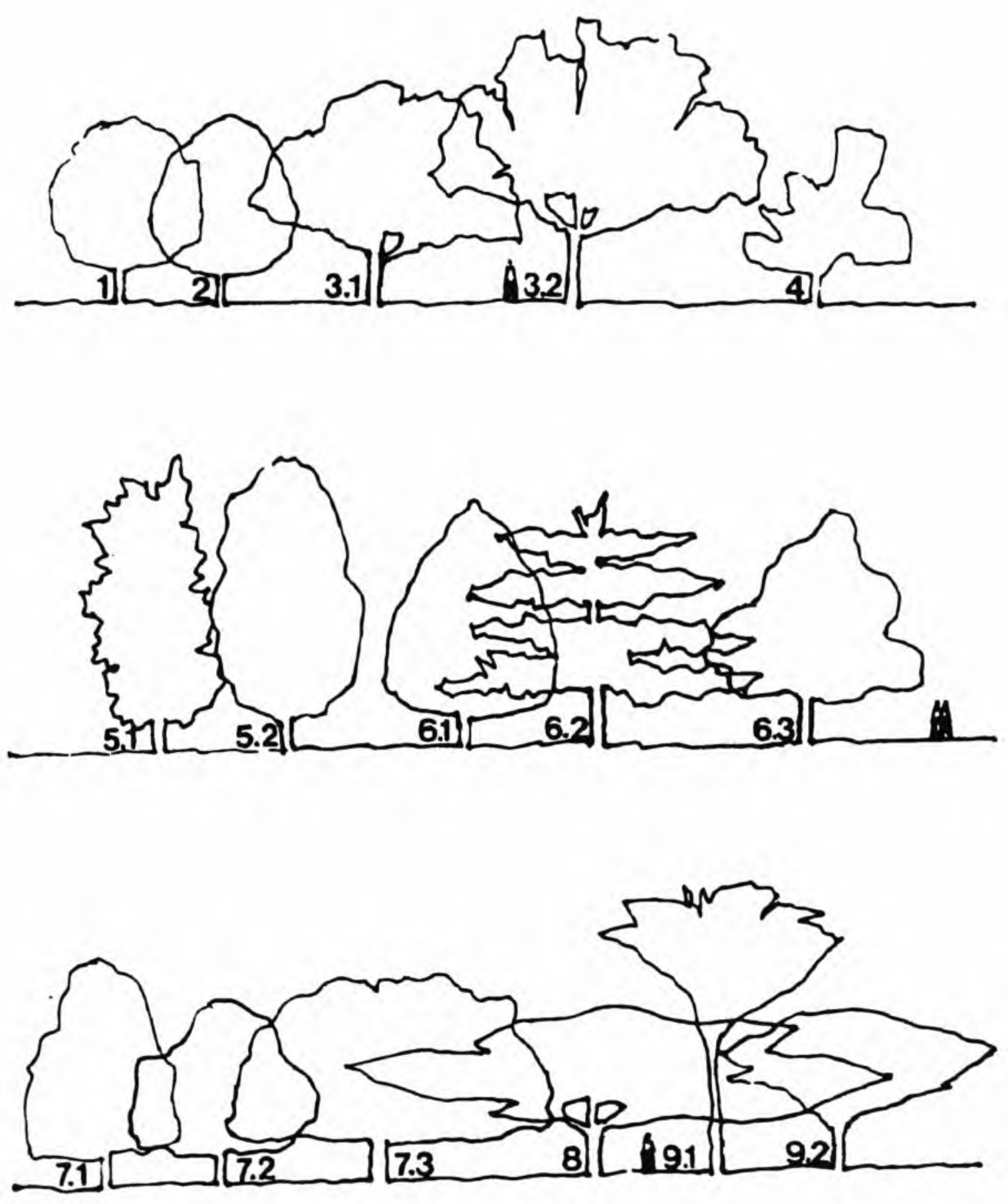

FORMAS DE ÁRVORES (exemplos) 1. Arredondada: Holocalix glazziovii (Alecrim-de-Campinas) 2. Ovalada: calophyllum brasiliense (olandi) 3. Em leque: 3.1 Adenanthera pavonina (tento-carolina) 3.2 Ochroma pyramidale (pau-de-balsa) 4. Irregular: Eugenia dysenterica (cagaita) 5. Colunar: 5.1 Triplaris brasiliense (novateiro) 5.2 Swietenia macrophylla (mogno) 6. Piramidal: 6.1 Eugenia malaccensi (jambo vemelho) 6.2 Terminalia catappa (amendoeira) 6.3 Vochisia pyramidale (pau-detucano) 7. Umbeliforme: 7.1 Pachira aquatica (munguba) 7.2 Tibouchina grandiflora (quaresmeira) 7.3 Ficus elastica (ficus-italiano) 8. Espalhada: Delonix regia (flamboiam) 9. Em cálice: 9.1 Schyzolobium parahiba (guapuruvu) 9.2 Dalbergia nigra (jacarandá da Bahia)

15 
O sombreamento proporcionado por uma árvore está relacionado principalmente com a densidade de sua folhagem, em função da qual a sombra projetada poderá ser densa, média ou rala. No caso da copa densa os raios de sol não chegam praticamente a atravessar a folhagem e o sombreamento provocado não permite o desenvolvimento de grama ou forrações na projeção da copa. É o caso, por exemplo, da munguba (Pachira aquatica) ou do amendoim-bravo (Pterogine nitens). Abaixo da copa das árvores de sombra média pode ocorrer o crescimento de plantas umbrófilas, sendo ainda considerável a proteção proporcionada pelo sombreamento que produz, como acontece com o pau-ferro (Caesalpinea ferrea), com o pequi (Caryocar brasiliense) ou com a sucupirabranca (Pterodon pubescens), enquanto no caso de sombra rala esta proteção torna-se pouco eficiente, como podemos ver, por exemplo, no angico (Piptadenia macrocarpa). As árvores com pouca densidade de folhagem podem ser muito úteis em situações onde se necessita de proteção contra a insolação, especialmente sol poente, sem obstruir muito o visual, pois a folhagem pouco densa chega a propiciar uma certa transparência que pode ser muito útil quando se quer proporcionar algum sombreamento sem comprometer totalmente as visuais de maior interesse.

Outro aspecto relativo ao sombreamento se refere à permanência da folhagem durante o decorrer do ano. Dizemos que uma árvore tem folhagem persistente, como a sibipiruna (Caesalpinea peltophoroides), ou ainda como o alecrim-deCampinas (Holocalix glazziovii), quando se encontra enfolhada durante o ano todo e a troca natural de folhas se faz sem que a copa se desnude acentuadamente. Nas árvores caducifólias, como acontece com a paineira (Chorisia speciosa) ou com o cambuí (Peltophorum dubium), a perda de folhas chega a ser praticamente total. Esta acentuada perda de folhas pode ocorrer, conforme a espécie, em razão da estiagem ou por ocasião do período de inverno.

Este primeiro conjunto de aspectos relativos ao porte, forma e sombreamento constitui a qualificação da árvore quanto à sua arquitetura de um modo geral, sem levar em conta os detalhes, definindo assim o modo como esta ocupa o espaço físico e o efeito que produz na paisagem enquanto elemento de forma e volume. Detalhando ainda mais esta caracterização, poderemos acrescentar uma série de aspectos complementares que dizem respeito às suas partes vegetais mais importantes.

Raiz e córtex: Em relação ao tipo de raiz é comum se distinguir árvores que possuem raízes pivotantes ou profundas (mogno, angico, pau-ferro) daquelas providas de raízes superficiais (flamboiam, guapuruvu, paineira). Estas são mais adequadas para os parques urbanos ou pisos extensos onde exista área suficiente para o desenvolvimento de sua estrutura de apoio, permitindo, quando for 0 
caso, tirar partido plástico das formas caprichosas e esculturais que poderão surgir, como acontece com algumas figueiras. Contudo é preciso se considerar que mesmo as árvores de raízes profundas, em especial as de maior porte, podem desenvolver raízes robustas próximo à superfície do solo, tornando-se um problema sério para as fundações dos edifícios ou para suas canalizações externas.

Como em certas situações pode ser indispensável o plantio de árvores na proximidade de construções ou mesmo estacionamentos e calçadas com o subsolo cortado por tubulações, é conveniente se utilizar nestes casos um artifício que, embora encareça o custo de plantação, poderá evitar alguns problemas futuros. A cova que receberá a planta deve ter suas faces verticais revestidas por uma parede de tijolos ou pedra até $60 \mathrm{~cm}$ de profundidade, deixando-se na superfície um espaço útil de aproximadamente $1 \mathrm{~m}^{2}$. Isto obrigará as raízes a se aprofundarem no solo evitando que interfiram com as fundações e com a infra-estrutura, possibilitando assim o plantio de árvores em locais onde de outra maneira isto seria desaconselhável.

O córtex ou casca da árvore é um revestimento de tecido formado por células mortas, que dá proteção mecânica e isolamento térmico ao caule. Seu aspecto varia muito com o tipo de árvore ou com sua idade. Nos indivíduos mais antigos pode se despreender em forma de placas cujo padrão é constante para cada espécie, servindo inclusive para sua identificação. Certas árvores do cerrado (cagaita, jacarandá, tamboril do cerrado) formam um córtex muito espesso, com profundos entalhes, originando desenhos de padrões que chegam a ser surpreendentes e se destacam principalmente na época em que as árvores se desnudam de suas folhas por ocasião da estação seca. Ainda, em caules onde existe uma camada superficial recobrindo outra, de coloração diferente, com o desprendimento parcial da primeira, pode-se ter como resultado um desenho de manchas de um efeito plástico extraordinário (pau-ferro, pau-mulato). Quanto ao córtex, portanto, é possível se fazer uma distinção entre dois tipos de árvores: aquelas em que este aspecto não apresenta maior interesse visual, geralmente de coloração acinzentada, e as que são providas de um tipo de córtex que as distingue nitidamente de outras espécies.

Folhagens, flores e frutos: Pode parecer irrelevante fazer distinçōes entre $o$ aspecto da folhagem das árvores, pois observando-se a paisagem, as massas vegetais por elas compostas são até certo ponto uniformes ou muito pouco diferenciadas, especialmente em nosso clima tropical, onde nem mesmo a variação das estações chega a produzir sensível modificação no aspecto da massa foliar, principalmente nas regiões onde a estação seca não é muito pronunciada. Entretanto, na pequena escala dos espaços livres bem delimitados e de tamanho re- 
duzido, detalhes menores como a textura da copa e as nuances de coloração da folhagem podem assumir importância significativa na caracterização do espaço.

Em relação à textura, as diferenças são sempre muito sutis e podem resultar de vários fatores como o tamanho e forma das folhas, sua organização nos ramos, padrão de distribuição e densidade. Contudo é possível simplificar a questão estabelecendo uma diferenciação de texturas baseada apenas na dimensão da lâmina foliar ou dos folíolos. Assim, podemos chamar de textura finíssima a que ocorre em casos muito particulares, nos quais a folhagem chega a dar a nítida impressão de um rendilhado de extrema delicadeza como, por exemplo, no caso do pau-mulato (Calycophyllum spruceanum) e do angico. A textura fina, bastante mais comum, pode ser atribuída a árvores cujas folhas também têm dimensões reduzidas, mas que podem chegar até aproximadamente $5 \mathrm{~cm}$, o que dá ao conjunto ainda um aspecto de grande leveza como na copaíba (Copaifera langsdorfii). Na textura média, folhas um pouco maiores, até $10-12 \mathrm{~cm}$ de comprimento, dão à copa um caráter de maior peso e acentuam sua presença na paisagem, como acontece com a mangueira (Mangifera indica). Folhas muito grandes, acima de $12 \mathrm{~cm}$, geralmente espessas, emprestam à árvore um caráter mais agressivo ou de maior solidez como no caso do pau-de-balsa e do Ficus lyrata.

Além destes quatro tipos de textura poderíamos acrescentar outros, mais específicos, entre os quais o mais significativo é o das árvores com folhas pingentes, como por exemplo o salgueiro chorão (Salix babylonica) onde o aspecto da copa é tão singular que a diferencia nitidamente dos outros tipos.

A coloração das folhas, embora sendo um aspecto de maior permanência que a floração, está longe de ter o mesmo efeito visual. A cor das folhas das árvores não chega mesmo a ser tão variada e atrativa quanto as dos arbustos, onde é muito comum a ocorrência de diferentes tipos de pigmentação. Podemos citar seis tonalidades diferentes mais comuns para as folhas das árvores: verde-médio, verde-escuro, verde-esbranquiçado, verde-acinzentado, verde-amarelado, verde-variegado, além da coloração prateada que é bastante típica, por exemplo, no eucaliptus argentino (Eucalyptus cinerea). O brilho também pode contribuir muito para distinguir as folhas, como no Ficus benjamim, uma pequena árvore muito utilizada em paisagismo.

São raros os trabalhos de paisagismo onde se nota uma atenção especial para a textura e coloração das folhagens. Raramente o nível de preocupação vai muito pouco além do uso da vegetação, baseado em seus aspectos de forma e volume e, quando muito leva-se também em conta a época e cor da floração. Isto não deixa 
de ser uma forma de empobrecimento, pela redução dos recursos disponíveis, deixando-se de lado aqueles que exigiriam um conhecimento mais aprofundado e maiores sutilezas no seu tratamento.

Relativamente as florações, embora seja grande o número de árvores que as produzem vistosas e atraentes (ipê, flamboiam, sibipiruna, paineira) sendo por isso muito cultivadas, como regra geral, são mais comuns espécies cujas flores são pouco atrativas, minúsculas e discretamente perdidas ou dissimuladas entre as folhagens, pouco se distinguindo destas (amendoim-bravo, alecrim-de-Campinas). Como as flores são órgãos de reprodução sexuada das plantas, cuja fecundação depende de agentes externos como o vento, insetos, pequenos pássaros, morcegos, toda sua aparência, cores, odores, secreções, existem ou deixam de existir em função do modo como são polinizadas. Muito comum entre as árvores é a polinização com o auxílio dos ventos, motivo pelo qual as flores de um grande número de espécies arbóreas não possuem maior interesse visual. Diversamente, as flores polinizadas por insetos, pássaros ou morcegos, são coloridas e vistosas, ocupando lugar de destaque na superfície externa da copa, freqüentemente perfurmadas e produtoras de néctar, características que geralmente as associam à percepção de seus agentes específicos.

Portanto, uma primeira distinção que se pode fazer em relação ao tipo de floração das árvores diz respeito ao fato de serem visualmente atraentes ou não. Um outro aspecto a se considerar é o que se refere à época e persistência da floração. Como as flores e frutos constituem importantes recursos alimentares para a fauna, é de se esperar uma certa distribuição de diferentes florações e frutificações ao longo do ano, o que efetivamente ocorre, embora com maior abundância em certos períodos, em função da variação climática. Espécies com floração contínua ao longo do ano constituem exceções, sendo mais comum que o florescimento ocorra em períodos determinados para cada espécie, embora possam acontecer variações de um ano para outro.

Aqui também é importante fazer uma distinção entre árvores em que a floração dura períodos mais ou menos longos (sibipiruna, cambuí), daquelas onde a floração irrompe toda ao mesmo tempo, de forma espetacular, com rápida duração (ipê, flamboian). Este efeito pode ser bastante acentuado no caso de árvores que perdem todas as suas folhas antes de florescer. O conhecimento preciso das épocas de florescimento pode ser muito útil para que se possa programar a ocorrência de floradas sucessivas, possibilitando uma variação de diferentes efeitos e combinação de cores ao longo do ano todo.

Seria praticamente impossível e até supérfluo citar a variedade de cores que ocorrem ante os diferentes tipos de flores, uma vez que provavelmente todas as 
nuances do espectro visível estão nelas representadas. Entretanto certas colorações são mais comuns em nossa flora, onde os tons de amarelo e azul são predominantes, enquanto espécies com flores vermelhas ou alaranjadas, por exemplo, são bem menos freqüentes, o que de certa forma explica o sucesso, entre nós, de algumas espécies exóticas, tais como o flamboian e a espatódea (Spatodea campanulata).

Menos espetacular que a floração, a frutificação é também um aspecto que pode distinguir certas espécies de árvores. Aqui, além da diferenciação entre frutificações atrativas e não atrativas será também importante fazer distinção entre as árvores com frutos comestíveis e não comestíveis. As fruteiras, ou árvores com frutos comestíveis, são relativamente pouco utilizadas no paisagismo urbano, em parte por um certo preconceito, mas também pela dificuldade concreta de manutenção, pois a maioria delas normalmente exige cuidados especiais de adubação, poda, controle de pragas e doenças, sem o que pouco ou nada chegam a produzir. Contudo, sempre será possível selecionar espécies rústicas de árvores com frutos comestíveis, menos exigentes de tratos culturais, que possam ser utilizadas também pelo seu valor ornamental.

\section{CONÍFERAS}

Sob o ponto de vista estritamente botânico as coníferas constituem uma ordem de plantas que pertencem às gimnospermas (plantas onde as sementes apresentam-se nuas, dispostas em pseudofrutos como, por exemplo, as pinhas) e que dispõem de um sistema de fecundação mais evoluído que o de outras gimnospermas e próprio das angiospermas (plantas com sementes encerradas em frutos). Para o paisagista, interessa mais o fato que as coníferas são um grupo de plantas de morfologia externa bem definida e reconhecíveis por uma série de características comuns que as diferenciam nitidamente das outras plantas.

Segundo este enfoque, as coníferas poderão ser consideradas como um grupo de plantas em sua grande maioria arbóreas, extremamente resistentes e pouco sujeitas a pragas e doenças, características de regiões de clima frio ou temperado e abundantes sobretudo no Hemisfério Norte. Sua forma, bem definida, é estruturada por um tronco único, reto e bastante elevado, com ramificações laterais regularmente distribuídas ao longo de todo seu comprimento, resultando em uma copa íntegra, bem composta, afilada e cônica. Seus ramos dispõem de folhas muito finas e resistentes, reduzidas a fiapos (acículas), a folhas muito estreitas e alongadas, ou ainda semelhantes a escamas, quase sempre bastante persistentes e adaptadas a resistir aos mais rigorosos invernos. Juntamente com a conforma- 
ção do fruto feminino, um cone formado por escamas resistentes e lenhosas, onde se encaixam as sementes nuas, estes são alguns dos aspectos mais importantes da conífera típica. Porém é importante salientar que existem muitos casos de exceção e as características citadas nem sempre comparecem em todas as espécies, servindo para referenciar o grupo apenas quando tomadas em seu conjunto.

As coníferas são plantas ancestrais que predominaram em eras passadas no globo terrestre e hoje, não mais no seu apogeu, cederam espaço para plantas mais evoluídas, as angiospermas, e retrocederam para regiões periféricas, de climas mais rigorosos, onde estão mais adaptadas que as outras espécies. Em paisagismo, constituem um grupo de plantas tão peculiar e atraente que, pela sua forma, pelas cores e tonalidades deslumbrantes que podem assumir ou pela delicadeza de suas texturas, não podem ser dispensadas facilmente. Nas regiões de clima temperado e frio, especialmente no Hemisfério Norte, chegam a ser utilizadas como componentes da estrutura do paisagismo de áreas de grande porte, comparecendo também com freqüência nos projetos de pequenos espaços como pátios e jardins, onde as formas arbustivas ou anãs são extraordinariamente apreciadas.

No Brasil, país de clima predominantemente tropical, em cuja flora nativa as coníferas constituem apenas raríssimas exceções, como é o caso pinheiro-doParaná, são mais cultivadas nos jardins e parques da região Sul do país, embora muitas delas possam se adaptar em zonas situadas mais ao norte, em especial nas de maior altitude. Muito cultivadas comercialmente, são vistas com algumas reservas pois, além de exóticas na sua grande maioria, simbolizam inequivocamente as paisagens das regiōes temperadas e frias do Hemisfério Norte, tanto quanto as palmeiras representam a vegetação tropical. Como, além disso, a grande maioria de nossas espécies nativas são escassamente conhecidas, poucas tendo sido introduzidas ao cultivo, poderá parecer estranho o interesse por tais espécies exóticas. Entretanto as coníferas constituem, pela sua aparência, forma, cor, textura, um grupo de plantas tão singulares e diferenciadas que sempre existirão situações específicas onde possam ser utilizadas adequadamente.

Porte e forma: $\mathrm{O}$ fato de terem colonizado em épocas remotas grande parte do globo terrestre, introduzindo-se nos mais variados habitats, deu origem a uma grande diversificação de portes e formas, podendo-se encontrar hoje entre as coníferas desde pequenos arbustos que nem mesmo chegam a atingir $1 \mathrm{~m}$ de altura após décadas de desenvolvimento, como acontece com grande variedade de cipreste anão, até formas arbóreas que facilmente ultrapassam os $100 \mathrm{~m}$ de altura, como é o caso das sequoias, que suplantam em muito as maiores árvores 
latifoliadas. As formas arbustivas, que existem em grande profusão, são na verdade variedades das espécies nativas comuns, geralmente criadas em viveiros a partir do cultivo intensivo das plantas originais, e denominadas cultivares. Não se encontram, entre as plantas tropicais cultivadas, uma igual quantidade de espécies arbustivas baixas, tão variadas em cores e texturas, e que, além disso, tenham um crescimento lento a ponto de dispensar podas freqüentes e replantios.

Dada a imensa variação de alturas encontradas entre as coníferas, podemos considerá-las distribuídas em cinco grupos: as de porte anão, com até $1,5 \mathrm{~m}$ de altura, representadas pela grande variedade de espécies arbustivas, muito comuns entre os cultivares de ciprestes e abetos, as de porte pequeno, que vão de 1,5 até $5 \mathrm{~m}$, mais raras, e que podem ser encontradas mais facilmente entre os juníperos, as médias, entre 5 e $15 \mathrm{~m}$, que também são pouco numerosas e podem ser encontradas em algumas espécies ou cultivares dos abetos e ciprestes, as altas, entre 15 e $25 \mathrm{~m}$ de altura, bastante mais numerosas, onde se incluem muitos tipos de pinheiros cultivados no Brasil, além do próprio pinheiro-do-Paraná. Restam finalmente as coníferas muito altas, acima de $25 \mathrm{~m}$, e que só podem ser plantadas em áreas muito extensas, como acontece com certos tipos de abetos e pinheiros que mesmo não chegando atingir, quando cultivados, a mesma altura das nativas, ainda assim ultrapassam facilmente as espécies latifoliadas.

Embora a conífera típica tenha sua altura de fuste praticamente desprezível, especialmente quando jovem, existe uma certa variação entre os tipos de fuste encontrados nas plantas que atingem sua maturidade, de tal forma que podemos adotar em relação às coníferas o mesmo critério adotado para as árvores:

fuste

muito baixo

baixo

médio

alto

até $2.5 \mathrm{~m}$

2,5 a $4 \mathrm{~m}$

além de $4 \mathrm{~m}$

Relativamente à copa é preciso lembrar que não são raras as formas amplas ou muito irregulares. Formas em chapéu de sol também, embora não muito comuns, existem em espécies muito importantes para o paisagismo como, por exemplo, o Pinus pinea, um tipo de pinheiro italiano cuja forma de certo modo se assemelha com a da Araucaria angustifolia, o nosso pinheiro-do-Paraná. Mais comuns, entretanto, são formas regulares e simétricas, entre as quais podemos citar as do tipo colunar, as cônicas e aquelas em forma de morro. Combinadas com os diferentes tipos de fustes que começam a surgir nas espécies que perdem seus ramos inferiores com a idade, resultam formas das quais representamos algumas das mais características: 


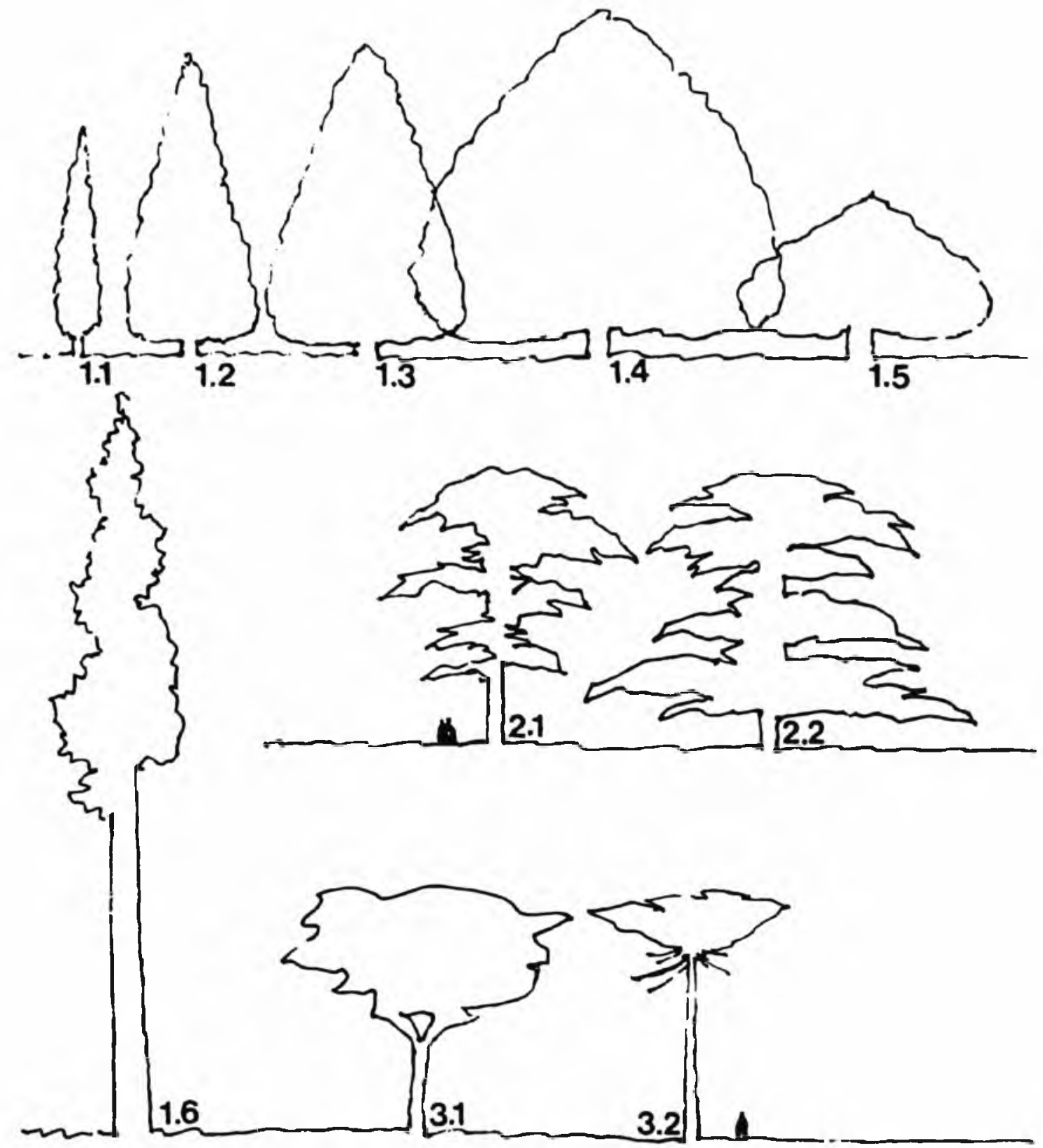

FORMAS DE CONIFERAS (exemplos) 1. Copa cônica: 1.1 Cupressus sempervirens (cipresteitaliano) 1.2 Thuia occidentalis (cedro-branco) 1.3 Thuia plicata (cedro-vermelho) 1.4 Cedrus deodara (dedro-do-Himalaia) 1.5 Taxus baccata (teixo) 1.6 Sequoiadendron giganteum (sequoia) 2. Copa espalhada: 2.1 Pinus sylvestris (pinheiro-bravo) 2.2 Cedrus libani (cedro-do-Líbano) 3. Copa em taça: 3.1 Pinus pinea (pinheiro-manso) 3.2 Araucaria angustifolia (pinheiro-do-Paraná)

Folhas, flores e frutos: São encontradas três tipos de folhas entre as coníferas: acículas, como no caso dos pinheiros (Pinus), lâminas alongadas, nos teixos (Taxus) ou escamas, como as que podem ser observadas nos ciprestes (Cupressus). A variação de cores e texturas das folhagens é muito grande e com 
freqüência as tonalidades são surpreendentes. Além dos matizes já citados para as árvores latifoliadas ocorrem muitos outros, como as diferentes tonalidades de azul, cinza, ferrugem, encontrando-se também folhagens douradas e prateadas.

As texturas são em geral delicadas e uniformes, mas, dependendo da maneira como as folhas se agrupam nos ramos podem surgir texturas compostas por conjuntos laminares como no caso das tuias, por "flocos" regularmente distribuídos na copa como em alguns casos de teixos ou ainda extraordinárias formas de folhagens pendentes, para o caso de folhas alongadas ou ramos flácidos como em algumas variedades de cedro ou ciprestes ou no Pinus montezumae, de origem mexicana, um dos pinheiros mais bonitos que existem.

Os frutos das coníferas, em geral, são cones de cor esverdeada, quando em formação, que se tornam castanhos ao amadurecer e raramente chegam a ser vistosos ou atraentes, embora em alguns casos tais frutificações possam ser realmente extraordinárias como quando ocorrem tons amarelos ou avermelhados que os destacam muito em contraste com as folhagens. Em alguns gêneros, como nos teixos, ocorrem frutos semelhantes a bagas, vistosos e perfumados, de uma brilhante coloração vermelha, mas que constituem casos de exceção.

\section{PALMEIRAS}

As palmeiras são plantas muito singulares pelo seu aspecto e únicas como elemento de destaque na paisagem. A palmeira típica tem seu caule esguio, vertical ou inclinado, às vezes tortuoso, coroado por uma roseta de folhas grandes e muito característica em forma de pena ou de leque, aspectos que as tornam insubstituíveis como elemento de referência e marcação da paisagem, utilizados isoladamente ou em diversos tipos de agrupamentos. Entretanto, nem todas se parecem com a palmeira típica: muitas espécies possuem troncos robustos, podem ter porte baixo ou ainda ocorrem em touceiras, existindo também as que se comportam como trepadeiras.

Plantas originárias das regiões tropicais, colonizaram um cinturão do globo entre os trópicos, pouco avançando além destes, embora existam raras espécies que podem ser encontradas em regiões temperadas como, por exemplo, a palmeiraleque européia, também chamada palmeira-da-Sicília, a Chamaerops humilis. Marcas características das zonas costeiras, são também encontradas no interior dos continentes, em habitats muito diversificados. De enorme importância na flora do Brasil, que já foi chamada de "terra das palmeiras" (Pindorama), representam um importante recurso ornamental em paisagismo, além de incalculável valor econômico. 


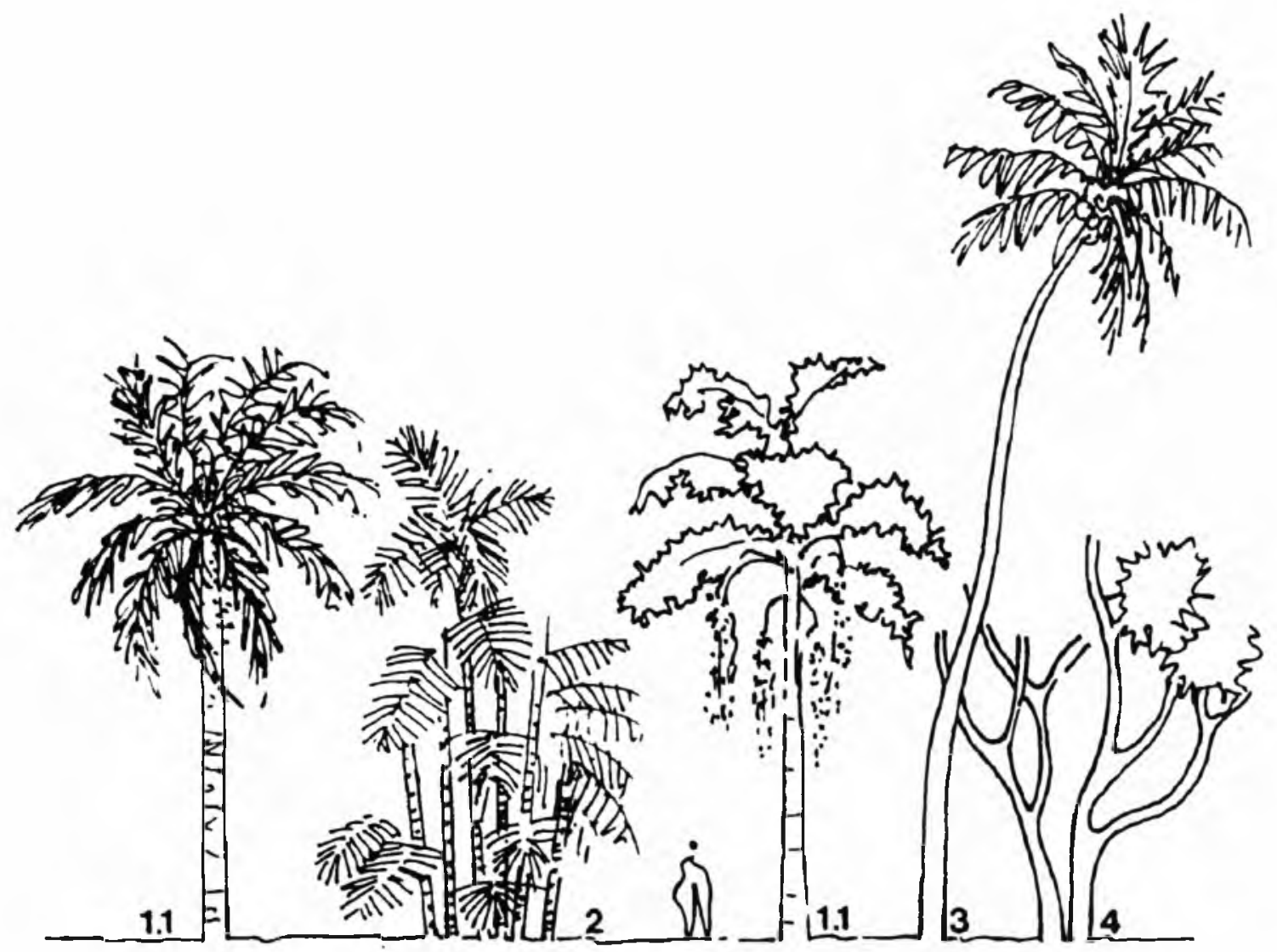

FORMAS DAS PALMEIRAS (exemplos) 1. Tronco simples: 1.1 Arecastrum roman=offiamum (jerivá) 1.2 Caryota urens (rabo-de-peixe) 2. Tronco múltiplo: Euterpe oleracea (açá) 3. Tronco inclinado: Cocos mucifera (coqueiro-da- Bahia) 4. Tronco dividido: gênero Hyphaene.

Porte e forma: As palmeiras apresentam uma constituição muito simplificada: um corpo de raízes fasciculadas que em geral se aprofunda relativamente pouco no solo sustenta um caule encimado por uma coroa de folhas que formam uma roseta na extremidade superior. Na sua base. o pecíolo das folhas envolve o caule, formando uma região característica, cuja dimensão varia com a espécie e constitui uma transição entre o caule e a copa. O caule, elemento fundamental na definição do porte e forma das palmeiras pode se apresentar extremamente diversificado conforme as espécies, variando muito em seu comprimento e podendo ser perfeitamente vertical, como no caso da palmeira-real (Roystonea oleracea), inclinado ou encurvado, como no coqueiro-da-Bahia (Cocos nucifera), simples. como no palmito-doce (Euterpe edulis) e no jerivá (Arecastrum romanzoffianum), ou múltiplo, como no caso do açaí (Euterpe oleracea). Apenas muito raramente pode ser ramificado. como no gênero Hyphaene ou assumir a forma de trepadeira. como no gênero Calamus, e ainda apresentar variações em seu diâmetro ao longo do comprimento, como acontece na palmeira-imperial (Roystonea regia). com sua típica forma de garrafa. Quanto ao aspecto da superfície do caule. esta pode ser praticamente lisa ou com anéis 
muito pouco pronunciados (palmeira-imperial), com ranhuras no sentido vertical (guariroba), fortemente anelada (jerivá), com espinhos (macaúba), provida de remanescentes do pecíolo (Corypha) ou das próprias folhas falsalatânia (Livistona chinensis).

O tipo de caule naturalmente ramificado é muito raro, mas pode ser induzido em determinados tipos de palmeiras que, uma vez seccionadas, regeneram-se produzindo ramificações. É importante ainda se fazer distinção entre palmeiras de caule único e múltiplo, uma vez que têm efeitos muito diversos na paisagem: uma palmeira que forma touceiras produz um efeito muito diferente das que possuem caule único, chegando a lembrar um grande arbusto. Isto fica muito claro quando comparamos duas palmeiras do mesmo gênero, a Cariota mitis (entouceirada), com a Cariota urens (tronco único).

Relativamente ao porte podemos considerar quatro tipos: as palmeiras praticamente desprovidas de caule aéreo, cujas folhas parecem nascer logo acima do nível do solo, como a Syagrus petraea, uma palmeira do cerrado conhecida como vassoura, as palmeiras de porte baixo, onde o caule não atinge mais do que $2 \mathrm{~m}$ de altura, como a palmeirinha-de-Petrópolis (Syagrus Weddelliana), as médias, cujo caule atinge aproximadamente $10 \mathrm{~m}$ como o jerivá, e as altas, como acontece com a palmeira-real, com espécies onde os caules facilmente ultrapassam os $10 \mathrm{~m}$ de altura, estas sim constituindo importantes elementos de referência na paisagem, podendo chegar a alturas incriveis. Embora raras palmeiras atinjam mais de $30 \mathrm{~m}$, em casos excepcionais, podem chegar até os $60 \mathrm{~m}$, como no gênero Ceroxylon, com uma importante espécie nativa dos Andes.

Quanto ao tipo de copa, existem duas formas bastante características: no caso de folhas cujos eixos são flexíveis, a forma da copa torna-se mais globular e bem distribuída no espaço como acontece com o jerivá. Quando este eixo é menos deformável, a copa assume a forma de um leque voltado para cima, como pode ser visto no babaçu (Orbignya speciosa) ou então em várias espécies do gênero Attalea, entre as quais o coco-indaiá, que é encontrado na região do cerrado.

Folhas, flores e frutos: A distinção mais importante que se pode fazer entre as folhas das palmeiras diz respeito ao tipo de disposição dos folíolos, que pode se dar em forma de pena (folhas pinadas), como acontece na grande maioria dos casos ou em forma de leque, às vezes bastante amplo e desenvolvido, dando assim origem às chamadas palmeiras-leque, com dois tipos diferentes: as de leque fechado, mais raras, como a Licuala grandis, e as de leque-aberto, como as latânias. Nas palmeiras mais comuns, de folhas pinadas, os folíolos são geralmente estreitos, dando à copa uma aparência de grande leveza. Nos casos em 
que as folhas apresentam folíolos mais largos, as palmeiras podem se tornar muito elegantes e vistosas como, por exemplo, a pinanga (Pinanga kuhlii) ou, ainda, em gêneros mais raros, que podem ter folhas semelhantes às das bananeiras.

As flores das palmeiras, que geralmente não chegam a ter um grande significado ornamental, agrupam-se em grandes cachos pendentes, com sua origem no ponto de inserção das folhas no caule, nascendo sempre protegidas por uma lâmina recurvada e dura denominada espádice. Quanto aos frutos, é importante distinguir entre os ornamentais que podem ser muito significativos pelo seu colorido, e aqueles sem interesse ornamental, da mesma forma que é necessário distinguir entre os comestiveis, em geral de extraordinária importância econômica, e os não comestíveis. É usual na linguagem popular se utilizar o termo "coqueiro" para designar as palmáceas, cujos frutos são comestíveis, reservando a palavra "palmeira" apenas para aquelas ornamentais. Entretanto, é bastante mais comum se utilizar "palmeira" para designar qualquer planta da família das palmáceas, indistintamente, como também é usual se designar por "coco" qualquer fruto das palmáceas, comestível ou não.

\section{TREPADEIRAS}

$\mathrm{Na}$ natureza, as trepadeiras são plantas desprovidas de caule resistente, que se desenvolvem apoiadas em plantas arbóreas e arbustivas, podendo chegar até a superfície exterior de sua copa, onde então passam a se desenvolver em plena luz solar, encontrando condições para o florescimento e frutificação. Desta forma, ao invés de investir seus recursos na fabricação de tecidos resistentes e lenhosos como o caule das árvores, produzem estruturas mais simples, leves e flexíveis, que lhes possibilitam um crescimento muito rápido em busca da luz solar. É comum que as trepadeiras tenham diferentes etapas de desenvolvimento, mais lento a princípio, até que se fixem a um apoio, quando passam a crescer rapidamente, mudando o tipo de folhas e alongando a distância entre os nós de seu caule.

Dentre os tipos de vegetais que foram definidos anteriormente, as trepadeiras constituem uma categoria de plantas muito especiais que se caracterizam, entre outras coisas, pelo seu polimorfismo. Certas espécies quando podadas segundo técnicas especiais podem adotar a forma de uma árvore, enquanto outras, quando não dispõem de um suporte adequado, assumem a forma de um arbusto ou, dependendo da consistência de seu caule, podem se desenvolver horizontalmente junto ao solo comportando-se como uma perfeita forração. Quando encontram uma estrutura que as suporte, desde que esta seja adequada ao seu tipo 
de fixação, expandem-se sobre ela, em geral com bastante rapidez, assumindo sua forma. São, assim, plantas ideais para recobrir cercas, muros, pérgolas, colunas, arcos e em certos casos servir como forrações recobrindo o próprio solo.

Porte e hábito: No que diz respeito a seu hábito podemos considerar a existência de três tipos de trepadeiras. No primeiro grupo estão plantas que não possuem qualquer órgão específico de fixação, além de seus caules muito longos, com ramificações e folhagens cuja disposição lhes permite uma certa ancoragem em outras plantas arbóreas e arbustivas, a qual vai se consolidando cada vez mais com seu crescimento. Esta ancoragem pode ser facilitada pela existência de espinhos nos caules ou nas folhas ou ainda pela adaptação de determinadas peças da planta, vindo a constituir órgãos muito rudimentares de fixação como é o caso de folhas pegajosas ou em forma de ganchos.

Neste primeiro grupo de trepadeiras encontram-se alguns tipos de cipós, como as primaveras (Bougainvillea), cujos caules flexíveis e resistentes curvam-se à medida que se alongam, produzindo novos ramos sucessivamente até encontrarem apoio. Encontram-se ainda plantas que formam ramos muito longos, mas tendem a tomar a forma de arbustos escandentes, desde que não amarradas a um suporte, como é o caso da congea (Congea tomentosa) ou de alguns tipos de jasmim. De modo geral estas plantas quando cultivadas podem necessitar de amarrações especiais a alguma estrutura de apoio sem as quais não assumem a forma adequada.

As trepadeiras, entretanto, podem ter seus próprios dispositivos de amarração, as gavinhas, que nascem em substituição a partes vegetais como folhas, ramos ou flores e possuem sensibilidade para se enrodilhar rapidamente em qualquer apoio próximo, como acontece com o amor-agarradinho (Antigonon leptopus) e o maracujá-azul (Passiflora caerulea). Juntamente com as trepadeiras que possuem raízes fixadoras, tais como a unha-de-gato (Ficus pumilla) e as heras, formam o segundo grupo: trepadeiras com órgãos específicos de fixação. Há dois tipos de raízes fixadoras, aquelas que criam pontos de sustentação ao se expandirem após sua penetração em fendas, e as que produzem um cimento que lhes possibilita aderir, mesmo em superfícies lisas.

Existe ainda um terceiro tipo de trepadeiras, cujos caules volúveis têm a propriedade de crescer em espiral, envolvendo qualquer suporte que lhes seja adequado, unindo-se a ele estreitamente. É o que acontece, por exemplo, com a madressilva (Lonicera japonica) e com jasmim-de-Madagascar (Stephanotis floribunda). Há mesmo o caso de plantas que tomadas como suporte deste tipo de trepadeiras sofram prejuízos, chegando a fenecer. 
As trepadeiras têm uma grande variação em relação ao porte, altura ou extensão que podem atingir, sendo útil considerar a existência de três grupos: pequenas trepadeiras, como a flor-de-cera (Hoy'a carnosa) ou a dama-da-noite (Cestrum noturnum), que não atingem mais do que 2 ou 3 metros, em geral com crescimento um pouco lento, servindo para cercas, pilares e treliçados baixos; plantas de porte médio, como o amor-agarradinho (Antigonon leptopus) e a lágrimasde-Cristo (Clerodendron thonsonae), boas para o revestimento de pergolados, treliças ou muros com altura de um pé direito simples, com ramos que não vão além de 5 ou $6 \mathrm{~m}$ de comprimento; trepadeiras grandes, como a sete-léguas (Pandorea ricassoliana) ou a glicínia (Winsteria sinensis), com ramificações muito longas, que em algumas espécies podem ultrapassar os $40 \mathrm{~m}$ de extensão. Neste último caso, como em geral tratam-se de plantas muito vigorosas, não se aconselha sua utilização em espaços com dimensões muito limitadas.

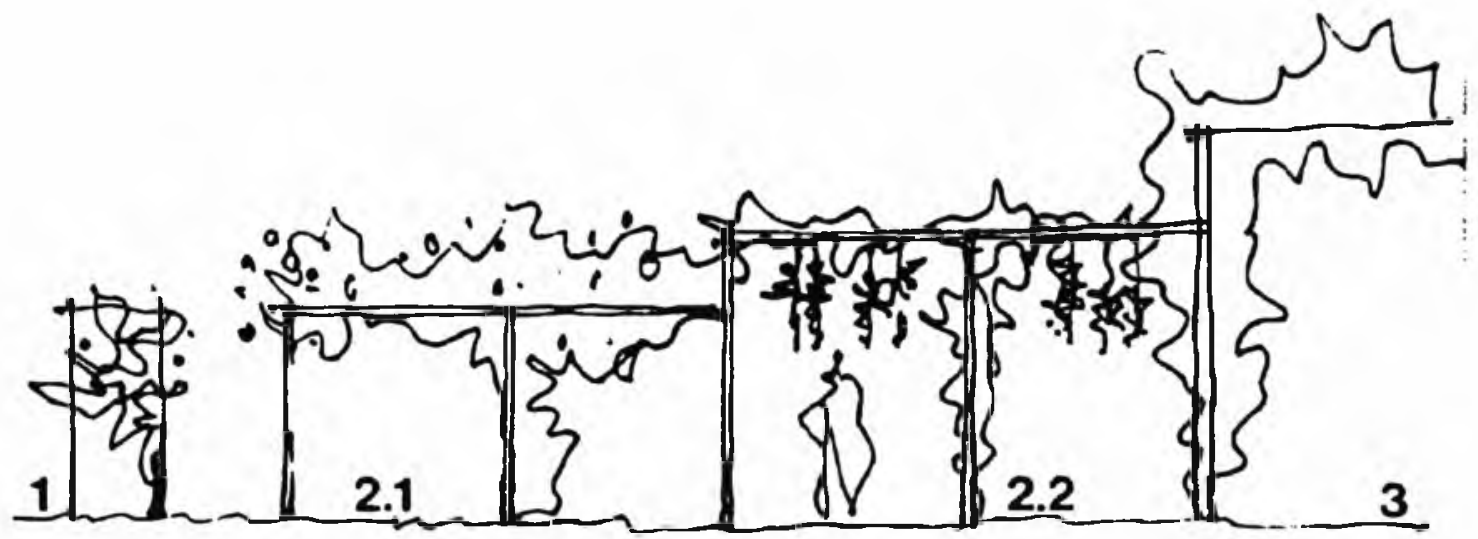

TREPADERAS (exemplos) 1. Pequeno porte Hoya carnosa (flor de cera) 2. Médio porte 2.1 Arrabidea magnificat (arrabidea) 2.2 Tumbergia misoriensis (sapatinho-de-judeu) 3. Grande porte - Pandorea ricassoliana (sete-léguas).

Folhas, flores e frutos: Quanto à sua estrutura, as trepadeiras assemelham-se muito a árvores de tronco e ramos muito esguios. As formas de suas folhas, entretanto, lembram muito mais aquelas dos arbustos, embora raramente sejam vistosas, a não ser no caso das aráceas, família onde são comuns as trepadeiras de folhas grandes, com desenhos caprichosos às vezes cobertas de manchas variegadas.

Já as flores de boa parte das trepadeiras são comumente muito vistosas, e constituem a principal razão para o seu indiscutível sucesso no mundo das plantas cultivadas. Em relação ao paisagismo é importante distinguir entre dois tipos de floração diferentes, pois enquanto existem trepadeiras cujas flores ornamentam a superfície externa de sua copa, como acontece na maioria dos casos, outras 
tornam-se especialmente interessantes quando observadas por baixo, uma vez que a floração ocorre em cachos pendentes, como, por exemplo, o sapatinho-dejudeu (Thumbergia misoriensis).

Não é incomum que trepadeiras possuam frutos grandes e às vezes vistosos ou então comestíveis, como nos diferentes tipos de maracujá. Isto acontece porque as trepadeiras são plantas que precisam crescer inicialmente dispondo de pouca iluminação, e devem poder contar com uma boa reserva de energia até que possam sintetizar por conta própria aproveitando a luz solar, apenas disponível acima das copas das plantas que lhes servem de suporte.

\section{ARBUSTOS}

Os arbustos formam um conjunto de plantas bem características, muito relacionadas com as árvores, diferenciando-se destas pelo seu porte menor, até aproximadamente $6 \mathrm{~m}$ de altura, e principalmente por terem seu caule repartido ao nível do solo. Constituem plantas normalmente muito resistentes e, como as árvores têm um período de vida bastante longo. Enquanto as plantas herbáceas possuem normalmente folhas de grandes proporções, com formas exuberantes, nos arbustos elas se apresentam semelhantes às das árvores e trepadeiras, sendo apenas mais freqüente a ocorrência de tipos de folhas variegadas, coloridas ou ainda manchadas por diversos matizes.

A forma peculiar dos arbustos, com seus diferentes caules aflorando junto ao solo, permite a formação de conjuntos vegetais uniformes onde as plantas perdem sua individualidade e passam a funcionar associadamente, o que pode ser muito útil para a formação de sebes, maciços ou cortinas vegetais.

Em paisagismo os arbustos constituem elementos de fundamental importância na organização do espaço exterior, sendo essencialmente utilizados como barreiras vegetais. Quando mal empregados podem trazer enormes prejuízos ao tratamento paisagístico chegando a comprometer ou destruir visuais importantes, podendo também obstruir trechos essenciais do espaço livre disponível.

Porte e forma: quanto ao seu porte podem ser distribuídos em dois grupos: arbustos de porte baixo, com altura até $1 \mathrm{~m}$, os quais, mesmo podendo constituir uma forte barreira física, não chegam a obstruir consideravelmente o campo visual e os de porte alto, acima da altura mencionada, que além de barreira física são capazes de limitar inteiramente o campo visual. Embora a grande maioria dos arbustos de clima tropical ultrapassem este limite de altura, existem 
muitas espécies de porte naturalmente baixo como, por exemplo, a violeta-docabo (Thunbergia erecta) ou a salvia (Salvia splendens). Podem ainda ser encontrados arbustos baixos entre as variedades anãs de plantas que normalmente possuem porte maior, como acontece com as azaléias (Rhododendron), que possuem diversas variedades anãs e a romanzeira (Punica), que possui a variedade denominada "nana".
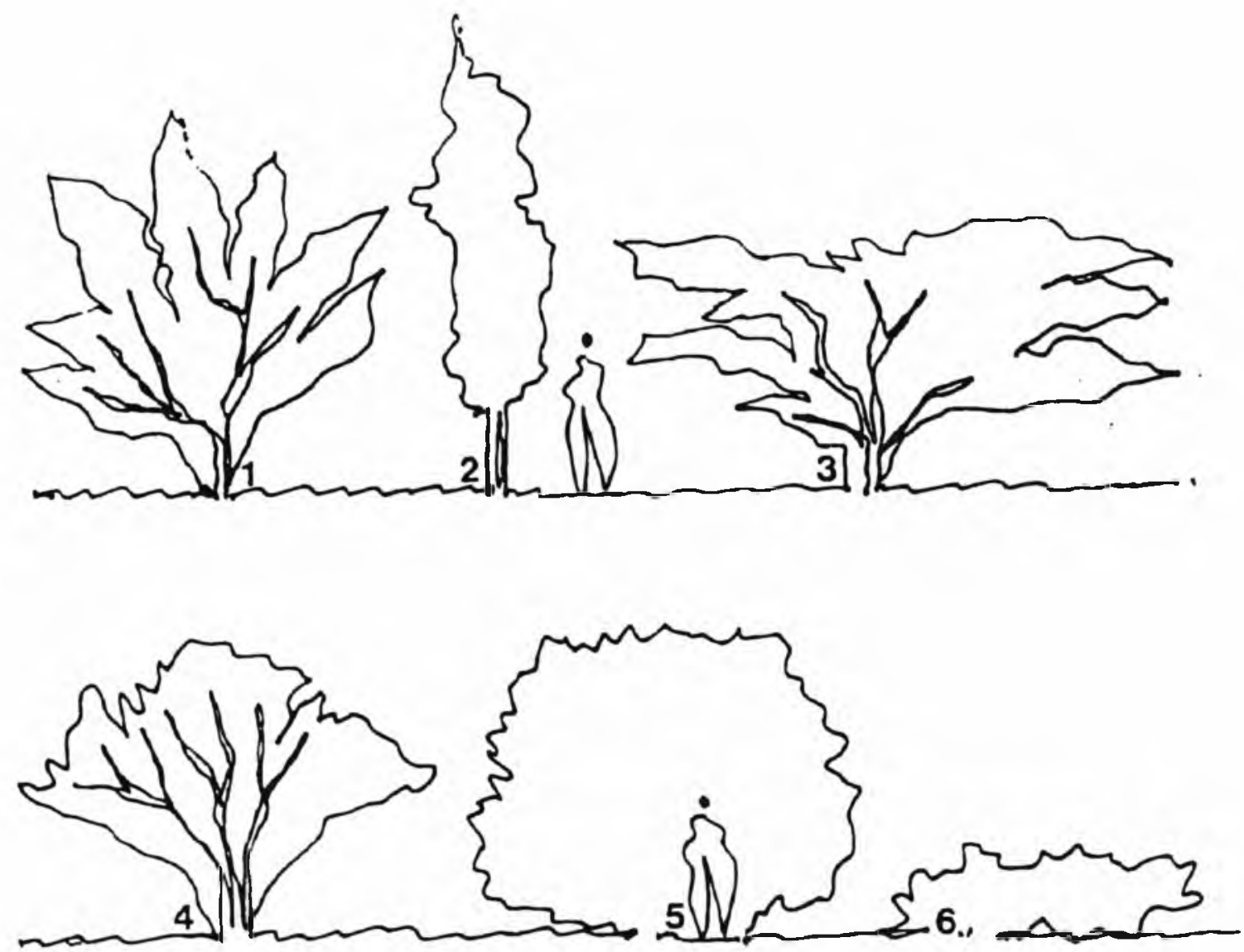

FORMAS DE ARBUSTOS (exemplos) 1. Espalhada vertical - Hibiscus rosa sinensis (papoula) 2. Colunar - Polyscias Balfouriana (cortina-de-pobre) 3. Espalhada horizontal - Euphorbia pulcherrima (bico-de-papagaio) 4. Leque - Nerium oleander (espirradeira) 5. Globular - Malvaviscus pendıliflorus (malvavisco) 6. Rasteira - Bucus sempervierns var. suffruticosus (buxo-anão).

Os arbustos altos, com porte acima de $1 \mathrm{~m}$, como o mimo-de-vênus (Hibiscus rosa-sinenesis), a fruta-de-jacu (Duranta celeste), a espirradeira (Nerium oleander), são em número muito maior, existindo ainda entre eles algumas espécies como a lantana (Lantana camara) ou a bela-Emília (Plumbago capensis) que podem ser mantidos baixos através de podas.

A forma dos arbustos varia muito de acordo com os tipos de caule, que podem se apresentar inteiramente lenhosos ou apenas parcialmente, com o lenho guarnecendo somente sua porção inferior e dispondo assim de um prolongamento 
herbáceo. A resistência do caule vegetal e também o tipo de ramificação que apresenta, constituem os dois fatores que definem a forma adotada pelo arbusto ao se desenvolver.

O arbusto típico é aquele cujos múltiplos caules são inteiramente lenhosos e voltam-se para cima, espalhando-se e desenvolvendo seus ramos mais ou menos regularmente no espaço, como é, por exemplo, o caso dos hibiscos (Hibiscus rosa sinensis). Quando os ramos se distribuem de maneira bastante homogênea temos como resultado uma forma que se assemelha aproximadamente a um leque, como no caso das espirradeiras (Nerium oleander). Quando estes caules crescem em direção acentuadamente vertical, como na cortina-de-pobre (Polyscias balfouriana) temos a forma colunar. Os que se desenvolvem mais horizontalmente ou lançam suas ramificações neste sentido, como a flor-de-SãoJoão (Euphorbia pulcherrima), constituem arbustos de forma espalhada ou horizontal. Arbustos que dispõem de prolongamentos de caule herbáceos longos, podem assumir a forma escandente e, dependendo da resistência da extremidade superior do caule, ou de suas ramificações, podem assumir a forma pendente, bastante característica e atrativa.

Folhagens, flores e frutos: Quanto aos aspectos relativos à folhagem, densidade da copa, textura e coloração das folhas, não são muito grandes as diferenças entre os arbustos e as árvores. Podemos fazer uma distinção inicial entre os arbustos que possuem copa densa, como o mimo-de-vênus (Hibiscus rosa-sinensis), capaz de obstruir drasticamente o campo visual daqueles nos quais a copa é menos compacta permitindo uma certa transparência, a exemplo do véu-denoiva (Euphorbia leucocephala).

Como a copa dos arbustos normalmente é observada segundo ângulos visuais e distâncias diferentes das que se costumam observar as árvores, seria mais apropriado estabelecer uma gradação de tipos de textura um pouco diferente da que foi fixada para estas. Neste caso, teremos: textura fina para os arbustos com folhas ou folíolos cujas dimensões em geral não ultrapassam os $4 \mathrm{~cm}$, como a mil-cores (Breynia nivosa) e o alfeneiro (Ligustrum ovalifolium), textura média para dimensões de folhas entre 4 e $12 \mathrm{~cm}$, como o mimo-de-vênus e o malvavisco (Malvaviscus penduliflorus), e grossa para as copas cuja dimensão média das folhas ultrapassa este último limite, como acontece com o bico-de-papagaio (Euphorbia pulcherrima).

Relativamente à coloração das folhas, podemos acrescentar às tonalidades já citadas para o caso das árvores (verde-claro, verde-médio, verde-escuro, verdeesbranquiçado, verde-acinzentado e verde-variegado), as folhagens de coloração avermelhada, tão comuns, por exemplo, em variedades da acalifa (Acalipha wil- 
kesiana), ou ainda as folhagens manchadas por tons de vermelho, verde e amarelo, tais como ocorrem nos diversos tipos de croton (Codiaeum variegatum).

Para as florações valem as mesmas considerações que foram feitas em relação às árvores, sendo necessário acrescentar apenas que, enquanto alguns arbustos são mais cultivados pela suas folhagens, outros destacam-se mais pelo aspecto de suas florações. É ainda importante mencionar a existência de arbustos, que se notabilizam pela peculiaridade de sua frutificação, como, por exemplo, o espinheiro branco ou Piracantha coccinea, admirável pela profusão de pequenos frutos vermelhos que produz.

\section{AS PLANTAS HERBÁCEAS}

As herbáceas são comumente definidas como plantas que apresentam o caule completamente desprovido de lenho, mas esta definição está longe de lhes fazer justiça. Na verdade, as plantas herbáceas se diferenciam das de maior porte. especialmente das plantas arbóreas e arbustivas, sobretudo por sua estrutura. Ao invés de possuírem um meristema que mantém sua predominância por um longo período, garantindo um extenso desenvolvimento no sentido longitudinal, e sem possuir também uma forma de crescimento modular, que lhes possibilite explorar o espaço circundante com maior amplitude, como o fazem certas árvores, as herbáceas produzem desde o início de seu desenvolvimento uma grande quantidade de ramos especializados na produção de flores.

No que diz respeito ao paisagismo, podemos dividir as plantas herbáceas em três grupos bastante diferenciados e com funções inteiramente diferentes na paisagem: as herbáceas erguidas, ou simplesmente herbáceas, as forrações, e os pisos vegetais.

As herbáceas propriamente ditas são plantas em geral até $1 \mathrm{~m}$ de altura, não raramente ultrapassando esta dimensão e que se destacam visualmente das forrações pelo seu porte maior, sendo apropriadas para a composição de maciços vegetais de altura e formas variadas, e ainda para serem utilizadas isoladamente ou em pequenos grupos. Diferenciam-se dos arbustos por não possuírem, em geral, o caule lenhoso, e ainda por suas florações mais abundantes. Conforme a espécie. distinguem-se também por suas folhagens exuberantes e variadas, muitas vezes com formas, desenhos e colorações bastante atraentes.

As forrações são, como o próprio nome indica, plantas rasteiras adequadas à formação de tapetes vegetais, recobrindo áreas mais ou menos extensas de terreno, sem chegar a constituir massa vegetal. Os pisos vegetais são constituídos 
por ervas cespitosas, que crescem horizontalmente sobre o terreno, muito resistentes ao pisoteio e às podas severas executadas rente ao solo, na sua grande maioria pertencendo à família das gramíneas.

Estes três tipos de plantas podem ser reunidos em composições vegetais, freqüentemente utilizadas nos tratamentos paisagísticos de áreas relativamente pouco extensas, quando se deseja um paisagismo colorido e diversificado. e se pode garantir um alto nível de manutenção.

\section{HERBÁCEAS}

Constituindo um grupo bastante peculiar, de grande utilidade para o paisagismo, não é muito fácil falar sobre as herbáceas de uma forma genérica e abrangente, sobretudo por causa da sua extrema diversidade. Embora existam muitas herbáceas bastante resistentes e duradouras, como regra geral são plantas que requerem maiores cuidados e manutenção que as plantas arbustivas ou arbóreas, exigindo, por vezes, replante ou substituição de tempos em tempos, ou ainda tratos culturais freqüentes e intensivos. Dispondo de raízes menos profundas e exigindo por vezes um sombreamento parcial, solo fértil e clima úmido, muitas herbáceas nem sempre poderão ser utilizadas no paisagismo extensivo, especialmente quando os recursos para manutenção forem muito limitados.

Dentro da categoria das herbáceas propriamente ditas, podemos considerar a existência de dois tipos de plantas que se diferenciam pela duração de seu ciclo de vida. As plantas de ciclo de vida curto ou anuais germinam, desenvolvem-se e florescem durante um curto período que geralmente se inicia na primavera e chega ao seu final antes do aparecimento do inverno. Algumas podem resistir por mais um ou dois anos, extinguindo-se após este período. Tais plantas são geralmente muito floríferas e adaptadas ao clima temperado, onde os invernos rigorosos impedem o crescimento vegetal. Muito utilizadas nos países do Hemisfério Norte, são menos difundidas nos países de clima tropical, inclusive o Brasil. onde são utilizadas apenas em casos especiais.

As plantas com ciclo de vida longo, também chamadas permanentes, embora muito raramente apresentem espécies com florações tão intensas e chamativas quanto as anuais, são muito mais duráveis. Por este motivo são preferidas em nosso clima, principalmente no tratamento paisagístico de grandes áreas, onde a substituição freqüente de espécies se tornaria proibitiva. Podem ser divididas em dois grupos: as de folhagem persistente, que se mantém sempre providas de folhas no decorrer do ano e as de folhagem caduca. Este segundo grupo é constituído por plantas que em certa época do ano, por ocasião do inverno, ou 
durante a estação seca, perdem completamente sua parte aérea, mantendo órgãos subterrâneos vivos em estado de dormência, dos quais, na época apropriada, brotarão novos rebentos.

Estes órgãos subterrâneos são de três tipos: os bulbos, que podem ser constituídos por uma série de camadas sobrepostas, como as cebolas, ou com sua porção central maciça, apresentando escamas só na superfície exterior (cormo), tal como se apresentam nos gladíolos. Os rizomas, caules que se desenvolvem horizontalmente abaixo da superfície do solo, tornando-se espessos, emitindo raízes e brotações e podendo assim se expandir para colonizar terrenos mais amplos, como acontece com as espécies de íris ou com o copo de leite. Os tubérculos, que podem ser de origem caulinar (túbera), como na batata inglesa e certos tipos de begônias, ou radicular (soqueira), como por exemplo no caso das clívias.

Porte e forma: Providas de uma estrutura mais simples que as plantas arbóreas e arbustivas, as hebáceas são de menor porte. sendo que a maioria de suas espécies não atingem mais do que $1 \mathrm{~m}$ de altura. Muito poucas entre elas, como algumas espécies da família das musáceas (entre as quais as bananeiras e helicônias), conseguem atingir um porte relativamente grande, podendo chegar a mais de $5 \mathrm{~m}$. Nestes casos, o reforço provido pelas bainhas das folhas, que se enrolam formando um caule herbáceo bem estruturado, proporciona resistência suficiente para que estas plantas assumam o porte comparável ao de uma pequena árvore.

A forma e estrutura das herbáceas é tão variada que apenas será possível dar alguns exemplos mais comuns ou significativos. Além da estrutura, a forma vai depender também dos tipos de folhas que podem ser exuberantes e vistosas.

Grande número das espécies herbáceas constituem comunidades, mantendo-se unidas por uma trama de raízes ou caules subterrâneos, enquanto é grande também o número daquelas que apenas se desenvolvem como plantas individuais. Neste último tipo é comum a estrutura de uma árvore em miniatura, onde o caule vai se dividindo sucessivamente, até chegar aos seus ramos floríferos. É bastante generalizada também a estrutura monopodial, na qual as folhas se inserem diretamente em um caule único, segundo diferentes tipos de disposições, opostas, alternadas, em espiral. No caso em que a distância entre os pontos de inserção das folhas no caule são sempre muito próximos, resulta a formação de uma espécie de roseta de folhas, tipo de estrutura também muito encontrada.

Folhas, flores e frutos: As herbáceas constituem um grupo de plantas onde se encontram grande número de espécies muito atraentes e extremamente diversificadas, que podem se distinguir pela singularidade de suas folhagens ou pela exuberância de suas florações. Embora mais sensíveis e exigentes que as árvores 
ou arbustos, tornam-se indispensáveis nos casos em que se requer um tratamento paisagístico mais variado e rico em detalhes.
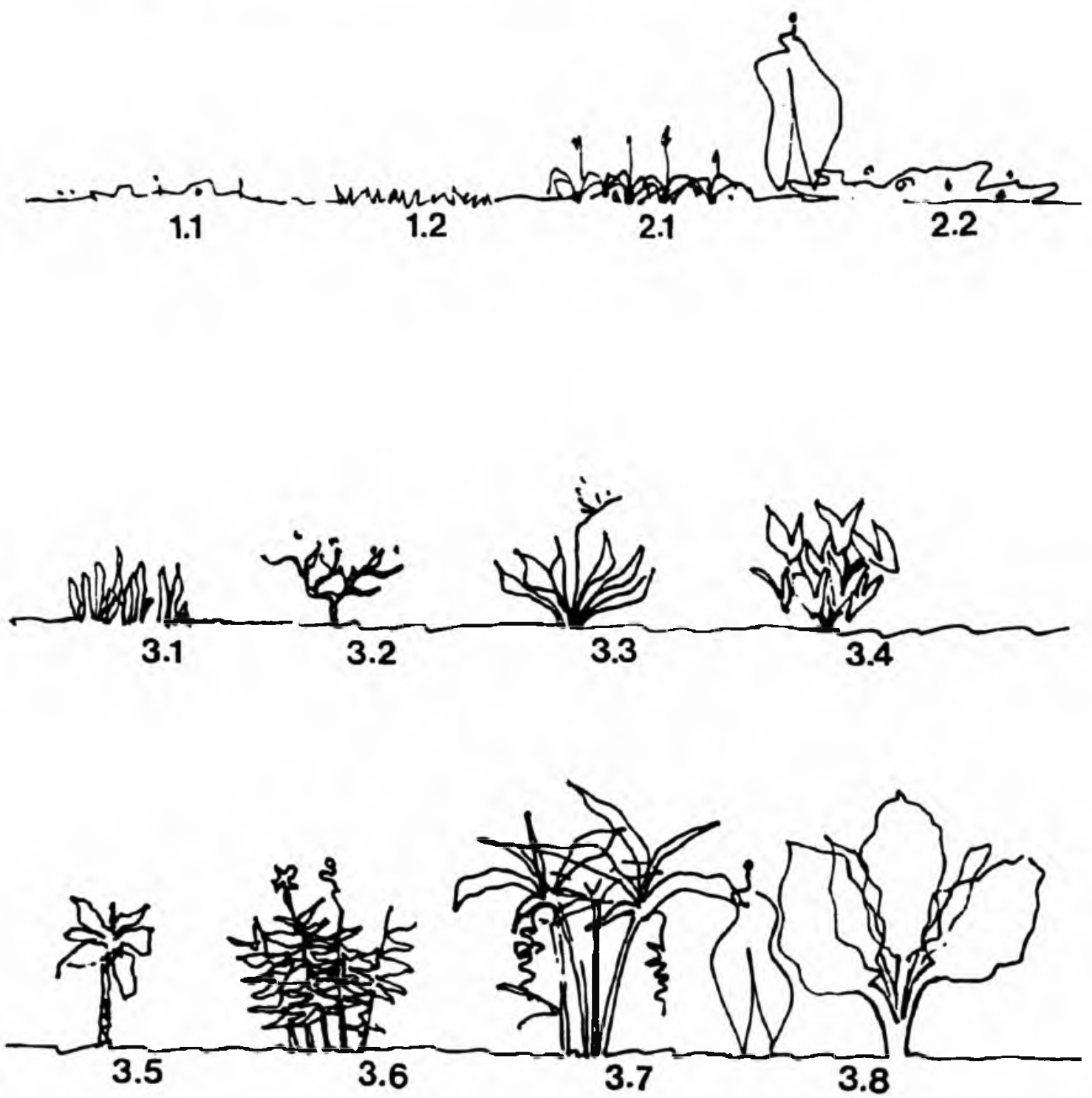

FORMAS DE PLANTAS HERBÁCEAS (exemplos) 1. Piso vegetal: 1.1 não gramínea Arachis prostata (amendoim rasteiro) 1.2 gramínea - Paspalum notatum (grama-batatais) 2. Forração: $2.1 \mathrm{sem}$ estolōes - Hemerocallis fulva (lírio-de-um-dia) $2.2 \mathrm{com}$ estolōes Wedelia paludosa (vedélia) 3. Herbácea erguida: 3.1 Sansevieria trifasciata (espada-de-São Jorge) 3.2 Impatiens walleriana (maria-sem-vergonha) 3.3 Strelitzia reginae (ave-do-paraiso) 3.4 Anthurium andraeanum (antúrio) 3.5 Dieffenbachia picta (comigo-ninguém-pode) 3.6 Hedichium coronarium (gengibre) 3.7 Heliconia rostrata (helicônia) 3.8 Alocasia macrorhiza (orelha-de-elefante)

Entre aquelas que se distinguem pela exuberância de suas florações encontramse a maior parte das espécies temporárias acompanhadas também por um bom número das permanentes. Entretanto, as espécies mais notáveis dentro deste 
grupo são as que se caracterizam pela singularidade da forma e dimensões de suas folhagens, freqüentemente exibindo desenhos e coloridos surpreendentes, como é o caso das aráceas e marantáceas, que são plantas adaptadas a lugares úmidos e sombreados, geralmente originárias das matas e florestas tropicais ou temperadas.

Assim, as folhas elípticas ou lanceoladas, ricamente decoradas das marantas e caláteas, as sagitadas do copo-de-leite, cordadas, oblongas ou profundamente partidas dos filodendros, recortadas e vazadas das monsteras, lineares das íris e dos fórmios, as gigantescas folhas de algumas espécies de Alocasia ou as folhagens imensas do Philodendron speciosum, que facilmente atingem mais de $1,5 \mathrm{~m}$ de comprimento, são apenas alguns dos inúmeros exemplos entre as espécies que podem introduzir maior grau de diversidade ou acrescentar desenhos e formas inusitadas no paisagismo, em contraste com a relativa uniformidade dos arbustos e das árvores. Muitas destas espécies como as helicônias, estrelícias, gengibres, notabilizam-se não apenas por suas folhagens, mas também pelas suas florações, tornando-se obrigatórias sempre que o detalhe e a diversidade vegetal sejam importantes.

A maior parte das herbáceas não apresenta frutificações que sejam de interesse ornamental. $\mathrm{Na}$ verdade boa parte das herbáceas cultivadas é reproduzida vegetativamente e nem chega a produzir frutos bem desenvolvidos ou com sementes viáveis. Há, entretanto, notáveis exceções como no caso de algumas aráceas que produzem frutos muito interessantes, compostos por um corpo em forma de espiga, parcialmente envolvido por uma capa recurvada, a espata. Muitas bromeliáceas têm florações e frutificações vistosas e até comestíveis como por exemplo o abacaxi, além de certas musáceas, como as helicônias, da mesma família à que pertencem as bananeiras.

\section{FORRAÇÕES}

Forrações são plantas herbáceas, prostradas, de caules rastejantes ou de porte muito baixo, com altura máxima ao redor de $30 \mathrm{~cm}$, não resistentes ao pisoteio, mas que por suas características de vigor e rusticidade podem cobrir densamente áreas mais ou menos extensas do terreno.

A altura da planta neste caso deve ser desprezível em relação à extensão da área coberta, de tal maneira que a cobertura vegetal possa ser percebida mais como elemento de superfície do que de volume, permitindo ao observador uma visão de conjunto, ampla e desimpedida. As herbáceas erguidas, como foram defini- 
das anteriormente, podem também ser utilizadas para cobrir trechos mais ou menos extensos de terreno, mas neste caso passam a ser vistas como maciços vegetais, constituindo antes elementos de volume que de superfície.

As forrações podem ser formadas pela justaposição de plantas independentes, se desenvolvendo em densas touceiras capazes de preencher totalmente os espaços intermediários, constituindo uma cobertura vegetal contínua e muito fechada, que impedirá a germinação de plantas invasoras dentro de seu território, como acontece, por exemplo, com os gêneros Hemerocallis, Alternanthera, Pilea.

Muito comumente, as coberturas vegetais podem ser constituídas por espécies que estabelecem comunidades extensas, e proliferam por intermédio de caules rastejantes, superficiais ou subterrâneos. Desenvolvem raízes em seus nós, originando novas plantas interligadas à planta-mãe, terminando por preencher todos os espaços intermediários e adjacentes, como acontece com a ajuga (Ajuga repens), a vedélia (Wedelia palludosa) e a trapoeraba (Zebrina pendula). Para algumas plantas, como é o caso da vedélia, este crescimento chega a ser tão rápido e vigoroso, que se torna indispensável a prática de podas freqüentes, sob pena de se ter toda a área disponível invadida por esta forração.

Da mesma forma que as herbáceas erguidas, as forrações podem ser constituídas por plantas de ciclo de vida curto ou por plantas permanentes. Também, como aquelas. são plantas bastante menos resistentes que as árvores e arbustos, necessitando de tratos culturais permanentes e, dependendo da espécie, replantes periódicos. Isto as torna inviáveis para paisagismo de áreas muito extensas, principalmente quando os recursos forem escassos.

Formas, folhas e flores: As forrações podem ser constituídas por uma enorme variedade de plantas, às vezes muito diferentes entre si, gramíneas suculentas, ervas prostradas, bulbosas, plantas anuais ou perenes, as quais, sempre de porte rasteiro, podem ser utilizadas para constituir múltiplas composições de formas, cores e texturas.

Entre as formas mais comuns de forrações estão as de folhas lineares. Algumas gramíneas com folhas deste tipo são utilizadas como forração, como é caso da grama azul (Festucsa glauca), notável pela sua coloração azul-prateada, ou ainda o capim australiano (Eragrostis curvula), com seus tufos de folhas finíssimas e alongadas, ambas espécies capazes de estabelecer um nítido contraste com outras forraçōes. A grama-preta (Ophiopogus japonicus), uma liliácea comumente confundida com as gramíneas, também faz parte deste tipo de forração, destacando-se pelas suas folhas finas de um verde muito escuro. $\mathrm{O}$ lírio-de- 
um-dia (Hemerocallis), também com folhas alongadas, tem uma textura mais grossa e suas flores, de pedúnculos alongados, formam um tapete colorido que se estende sobre as folhagens desta forração.

Muito atraentes entre os diferentes tipos de forrações são aquelas que dispõem de folhagens coloridas, e servem para estabelecer vivos contrastes com outras espécies. A cotonária (Helichrysum petiolatum), com sua cor prateada, a Setcreasea purpúrea com sua vistosa coloração púrpura, a Hemigraphis colora$t a$, de uma incomparável coloração roxo-escura, ou ainda a brilhantina (Pilea muscosa), de tonalidade verde-clara bastante incomum, constituem algumas espécies indispensáveis quando se pretende obter uma composição de forrações atraente e diversificada. Muito importantes também são as forrações que possuem florações vistosas e persistentes, sejam elas plantas persistentes, vivazes ou mesmo anuais.

\section{PISOS VEGETAIS}

Pisos vegetais são plantas de crescimento rasteiro, resistentes ao pisoteio e que admitem podas drásticas, rentes ao solo. A maior parte dos pisos vegetais cultivados é constituído por plantas da família das gramíneas e só muito raramente outras plantas de famílias diferentes são utilizadas como pisos vegetais como, por exemplo, é o caso do amendoim rasteiro (Arachis prostrata), uma leguminosa que por suas qualidades de forte enraizamento, crescimento prostrado e folhagem miúda e resistente, pode substituir o gramado, principalmente em locais onde o pisoteio não é muito freqüente.

Por sua vez, as gramíneas constituem uma família de plantas bastante extensa e diversificada, presente em todos os tipos de paisagens naturais, resistindo e adaptando-se às condições mais adversas. Apesar de serem muito numerosas, as espécies que pertencem a esta família, apenas uma pequena porcentagem é cultivada como ornamental e poucas dentre elas se prestam a serem utilizadas como pisos vegetais.

A maior parte das gramas cultivadas como pisos vegetais possui estolōes ou rizomas, que são prolongamentos horizontais do caule, subterrâneos ou superficiais que, no caso dos estolões, enraízam nos nós e produzem novas plantas e, tratando-se de rizomas, formam novas plantas nas suas extremidades. Em ambas situações os gramados tornam-se densas comunidades de plantas que chegam, como no caso da grama-batatais (Paspalum notatum), a cobrir rapidamente o terreno disponível e ainda podem invadir os espaços vizinhos. Esta espécie é notável também por formar gramados que são resistentes ao fogo. Nativa do cerrado a grama-batatais, por ocasião das queimadas, tem apenas sua parte 
aérea afetada pelo fogo, mantendo-se viva abaixo da superfície do solo, pronta para rebrotar tão logo as condições externas o permitam.

Folhas, flores e frutos: Entre as espécies mais comuns de pisos vegetais cultivados, as principais variações no seu aspecto residem nas diferenças de coloração e textura. A coloração da folhagem se restringe a algumas tonalidades de verde, raramente apresentando variações mais significativas, como, por exemplo, no caso da grama-inglesa, que tem uma variedade verde-amarela na espécie denominada Stenotaphrum secundatum var. variegata, cujas folhas apresentam listas longitudinais amareladas.

Diferenças de textura são mais notáveis, no caso das gramas, que se podem apresentar com uma textura fina, como no caso da grama-bermudas ( $C$ ynodon dactilon) ou da grama-coreana (Zoysia japonica), cujas folhas não chegam a $0,5 \mathrm{~cm}$ de espessura, com textura média, como por exemplo a grama-batatais, com folha de espessura até um máximo de $1,5 \mathrm{~cm}$ de largura, ou ainda com textura grosseira, no caso de gramas com folhas mais largas que $1,5 \mathrm{~cm}$, como por exemplo a grama-de-folha-larga (Axonopus obtusifolia).

\section{PLANTAS ATÍPICAS}

Na sua maioria as plantas cultivadas enquadram-se em um dos tipos vegetais descritos anteriormente, porém, há um certo número de espécies que mesclam diferentes características de dois ou mais tipos. Além disso, algumas famílias, como, por exemplo, as cactáceas, ou mesmo grupos de espécies pertencentes a famílias diferentes, como as suculentas, guardam semelhanças tão próximas entre si, e tão diferentes das outras espécies, que embora não devam propriamente ser considerados tipos vegetais, ainda assim podem ser vistos como grupos especiais.

As plantas atípicas ou grupos diferenciados mais comuns, em última análise, sempre poderão ser considerados como pertencendo a um ou mais dentre os tipos vegetais descritos. As principais entre elas são:

1. Bambus e gramíneas altas: os bambus são plantas que pertencem à família das gramíneas, com altura não raramente similar ao das grandes árvores, formando múltiplos caules subdivididos abaixo da superfície do solo e originando densas touceiras, pelo que podem ser considerados como se fossem grandes arbustos. Seus caules, vazados interiormente e marcados por nós bastante regulares, sustentam folhas muito leves que oscilam com facilidade quando impulsionadas pela mais leve aragem. 
Existem dois tipos de bambus: aqueles cujas touceiras crescem em tamanho e densidade, mas se mantêm dentro de uma zona razoavelmente delimitada, e os que possuem a propriedade de emitir extensos estolões por baixo da terra, formando touceiras muito abertas que ocupam grandes áreas de terreno. Algumas gramíneas altas, como o capim-dos-Pampas ou Cortadeira sellowana, são muito utilizadas em paisagismo e embora não sejam arbustos, produzem efeito similar na paisagem.

2. Bromélias, dracenas, agaves e yuccas: embora sejam plantas de diferentes famílias, relacionam-se muito pela sua estrutura e aspecto visual. Com suas folhas alongadas, distribuídas regularmente ao redor do caule, podem formar rosetas perfeitas como as agaves e bromélias, ou alongadas como as yuccas, dependendo do comprimento do caule. Esta estruturação de folhas é tão característica que as distingue claramente das outras plantas, motivo pelo qual são freqüentemente utilizadas como elementos de destaque no paisagismo, sendo até usual se adotar uma representação gráfica em projetos, que evidencie sua distinção das outras plantas.

As dracenas e yuccas são normalmente usadas como arbustos, arboretas ou mesmo árvores, enquanto as bromélias e agaves, em geral de menor porte, podem ser empregadas como herbáceas ou em certos caso como plantas arbustivas. Agaves e yuccas são também plantas suculentas, embora seu aspecto visual as aproxime muito das dracenas e bromélias.

3. Suculentas e cactáceas: as suculentas constituem um extenso grupo de plantas caracterizadas pela sua capacidade de acumular água em seus tecidos, motivo pelo qual apresentam, com freqüência, folhas e caules espessos. Em geral são plantas de clima seco, mas podem ocorrer também em matas úmidas, sob a forma de plantas epífitas, crescendo sobre o caule de plantas arbóreas. Conforme a espécie podem ser utilizadas como forrações, herbáceas ou, em alguns casos, arbustos.

As cactáceas são plantas suculentas que pertencem a uma família botânica bastante diferenciada, apresentando certas adaptações, tais como o caule inchado e folhas transformadas em espinhos. Estas características reduzem ao extremo a transpiração, o que as torna plantas muito adequadas à sobrevivência em climas quentes e secos, podendo passar vários meses sem chuvas.

Boa parte das cactáceas e suculentas são mais apropriadas para vasos ou jardins rochosos, ou ainda para serem utilizadas em trechos mais ressequidos da paisagem, onde podem ser cultivadas em ambiente mais apropriado às suas caracte- 
rísticas naturais. Muitas espécies, entretanto, têm uma utilização mais ampla e extensiva, sendo normalmente empregadas, dependendo da espécie. como forrações, herbáceas ou arbustivas.

4. Samambaias-açu e cycas: as samambaias-açu pertencem ao grupo das pteridófitas, a família botânica das samambaias. Diferenciam-se das outras samambaias por possuírem um tronco fibroso e resistente, que pode se desenvolver com altura suficiente para que samambaias-açu possam ser consideradas como arvoretas ou mesmo árvores, com folhas muito grandes e leves, típicas desta família de plantas.

As cycas, embora façam parte das coníferas, pelo tipo de frutificação que produzem, são muito assemelhadas às palmeiras, podendo ser incluídas entre estas na classificação anteriormente adotada para os tipos vegetais.

5. Bananeiras e helicônias: como já foi dito anteriormente, as bananeiras e algumas helicônias de maior porte, apesar de não produzirem lenho, podem dispor de um caule resistente e bem desenvolvido, pelo que assumem a forma de arvoretas ou pequenas árvores, mantendo as folhagens amplas e vistosas, típicas das herbáceas.

6. Filodendros e monstera: também com folhas amplas, recortadas ou vazadas, características das plantas herbáceas, alguns filodendros, como o imbé (Philodendron bipinnatifidum), da mesma forma que a costela-de-Adão (Monstera deliciosa), podem assumir o porte arbustivo ou, se têm a sua disposição um suporte adequado, se tornar trepadeiras vigorosas e notáveis.

7. Aquáticas e epífitas: as plantas aquáticas costumam ser divididas em três categorias: as flutuantes, cujas raízes não chegam ao solo como o aguapé (Eichornia crassipes), as que se enraízam no fundo e permanecem sob a água, mais utilizadas para equilibrar o ecossistema aquático, e as que enraizando-se no fundo se desenvolvem acima da superfície com folhagens flutuantes como as ninféas (Ninphaea) ou aéreas como o papiro (Papirus). As flutuantes e as que se desenvolvem sobre a superfície podem ser vistas como forraçōes ou como herbáceas, dependendo da espécie, chegando nos casos onde ocorra a superpopulação de plantas, como em tanques ou espelhos-d'água mal cuidados, a descaracterizar completamente o efeito produzido pela água, passando a funcionar visualmente, como se fossem simples canteiros em terreno firme.

Espécies que se desenvolvem sobre o caule de outras, sem chegar com suas raízes ao solo, parasitando ou não a planta hospedeira, constituem um grupo de 
plantas tão específico que não se enquadram em nenhum dos tipos descritos. No paisagismo estas plantas poderão ser utilizadas apenas como complementos, sem chegar a participar da estrutura da composição propriamente dita.

\section{CONCLUSĀO}

A categorização de tipos vegetais conforme foi estabelecida, permite uma abordagem gradual do estudo da vegetação dentro de um projeto de paisagismo, trabalhando-se inicialmente com aspectos mais gerais como forma e volume e chegando-se aos poucos aos aspectos mais particulares e detalhados, até que se chegue à especificação propriamente dita. Saber explorar todos os aspectos, mesmo os mais sutis, como textura, coloração, tonalidades, por exemplo, vai sem dúvida exigir um conhecimento apurado das espécies vegetais, o que só será possível através de uma ampla experiência, e mesmo uma certa convivência com as espécies vegetais, apoiada por informações precisas sobre todas as peculiaridades de cada espécie, obtidas na bibliografia específica, as quais nem sempre existem ou são encontradas facilmente.

Outro aspecto importante a se considerar é que as plantas nunca são utilizadas isoladamente, mas sempre em conjunto, formando associações vegetais, dentro da quais, suas características peculiares podem sofrer algumas modificações. É muito comum em paisagismo a utilização de grupos homogêneos de plantas, artifício utilizado para reforçar a presença de uma determinada espécie vegetal, especialmente em espaços de grandes dimensões. Este tipo de associação, por similaridade, pode ser obtido com plantas da mesma espécie ou que se assemelham entre si. Muito comum também é o emprego de associações de plantas que contrastam pela forma, textura ou cores, obtendo-se assim efeitos vivos e atraentes.

Algumas espécies vegetais são mais adequadas quando utilizadas como elementos de destaque na paisagem, enquanto outras prestam-se mais à formação de massas vegetais com aspecto neutro, utilizadas em segundo plano, para delimitação do espaço ou fechamento da composição.

Eventualmente, dependendo das circunstâncias, a mesma espécie pode ser utilizada ora como elemento de destaque, ora como massa vegetal neutra.

Da mesma forma como definimos os tipos vegetais, é possível se falar em tipos de associações vegetais como, por exemplo, alamedas, bosques, cordões vegetais, renques de palmeiras, massas arbustivas, massas compostas por arbustos associados a árvores, composições de forrações, conjuntos formados por forra- 
ções e herbáceas, e ainda um sem número de outros tipos de combinaçōes possíveis. Contudo esta discussão foge ao escopo principal do presente trabalho.

Resta finalmente reforçar o que foi dito no início, a respeito da relação da vegetação com o seu ambiente. Embora as plantas cultivadas tenham uma grande capacidade a se adequar ao ambiente. existem limites que precisam ser conhecidos. Algumas espécies são muito pouco exigentes e por isso mesmo utilizadas com muita freqüência nas mais diversas situaçōes, enquanto outras. adaptadas apenas a condiçōes mais restritas, têm que ser utilizadas com maior cuidado. Nos casos em que se pretenda um paisagismo mais exuberante ou de maior qualidade visual, é conveniente que seja previsto desde o projeto arquitetônico à existência de ambientações variadas, que permitam uma aplicação mais rica e diversificada dos recursos vegetais.

\section{BIBLIOGRAFIA}

BAILEY, L. H. Manual of Cultivated Plants. New York: MacMillan Publishing Co., Inc., 1951.

BLOSSFELD, H. Jardinagem. São Paulo: Melhoramentos, 1964.

BONDAR, G. Palmeiras do Brasil. Secretaria de Agricultura do Estado de São Paulo Instituto de Botânica, 1964.

BROWN, L. Grasses: An Identification Guide. Boston: The Peterson Nature Library, 1979.

BRUCE, H., altri. Taylor's Guide to Shrubs. Boston: Houghton Mifflin Company, 1987.

CHANES, R. Deodendron. Barcelona: Editorial Blume, 1969.

CORREA, M. P Dicionário das plantas Úteis do Brasil. Rio de Janeiro: MA-IBDF, 1974.

FERRI, M. G. Botânica: morfologia externa das plantas. São Paulo: Nobel, 1982.

GRAF, A. B. Tropica. New Jersey: Rohers Co. Publishers, 1978.

HALLE, F. \& Altri. Tropical trees and forests, an architectural analysiss. Berlim: Springer-Verlag, 1978.

HERKLOTS, G. Flowering tropical climbers. Dawson Science History Publications, 1966. 
HOYOS, J. Flora tropical ornamental. Caracas: Sociedad de Ciencias Naturales La Salle, 1978.

JOHNSON, H. The international book of trees. London: Mitchel Bearley Limited, 1977.

JOLY, A. B. Botânica: Introdıçāo à taronomia vegetal. São Paulo: Companlia Editora Nacional, 1976.

KUNKEL, G. Flowering trees in subtropical gardens, Dr. W. Junk b.1.. Publishers, The Hague, 1978.

LANZARA, P., Pizzetti, M. Guide to trees. New York: Simon Schuster Inc., 1977.

MCCURRACH, James C. Palms of the World. New York: Harper \& Brothers, 1977.

OAKES, A. J. Ornamental grasses and grasslike plants. New York: Van Nostrand Reinhold, 1990.

PAPWORTH, D. A Gardener's guide to conifers. London: Salamander Books Ltd., 1988.

PRANCE, G.T., Silva, M. F. Án'ores de Manaus. Manaus: INPA, 1975. 